\title{
Anti-Virulence Therapeutic Approaches for Neisseria gonorrhoeae
}

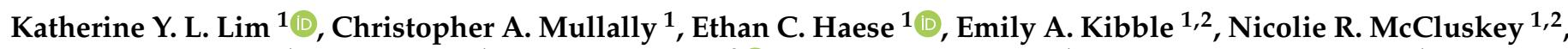 \\ Edward C. Mikucki ${ }^{1}$, Van C. Thai ${ }^{1}$, Keith A. Stubbs ${ }^{3}{ }^{\mathbb{D}}$, Mitali Sarkar-Tyson ${ }^{1}$ and Charlene M. Kahler ${ }^{1, *}$ \\ 1 Marshall Centre for Infectious Disease Research and Training, School of Biomedical Sciences, \\ University of Western Australia, Crawley, WA 6009, Australia; \\ katherine.lim@research.uwa.edu.au (K.Y.L.L.); christopher.mullally@research.uwa.edu.au (C.A.M.); \\ ethan.haese@research.uwa.edu.au (E.C.H.); emilyalice.kibble@murdoch.edu.au (E.A.K.); \\ nicolie.mccluskey@murdoch.edu.au (N.R.M.); edward.mikucki@research.uwa.edu.au (E.C.M.); \\ vanchi.thai@research.uwa.edu.au (V.C.T.); mitali.sarkar-tyson@uwa.edu.au (M.S.-T.) \\ 2 School of Veterinary and Life Sciences, Murdoch University, Murdoch, WA 6150, Australia \\ 3 School of Molecular Sciences, University of Western Australia, Crawley, WA 6009, Australia; \\ keith.stubbs@uwa.edu.au \\ * Correspondence: charlene.kahler@uwa.edu.au
}

Citation: Lim, K.Y.L.; Mullally, C.A.; Haese, E.C.; Kibble, E.A.; McCluskey, N.R.; Mikucki, E.C.; Thai, V.C.; Stubbs, K.A.; Sarkar-Tyson, M.; Kahler, C.M. Anti-Virulence Therapeutic Approaches for Neisseria gonorrhoeae. Antibiotics 2021, 10, 103. https://doi.org/10.3390/

antibiotics 10020103

Academic Editor: Angela Brown Received: 23 November 2020 Accepted: 20 January 2021 Published: 21 January 2021

Publisher's Note: MDPI stays neutral with regard to jurisdictional claims in published maps and institutional affiliations.

Copyright: (c) 2021 by the authors. Licensee MDPI, Basel, Switzerland. This article is an open access article distributed under the terms and conditions of the Creative Commons Attribution (CC BY) license (https:/ / creativecommons.org/licenses/by/ $4.0 /)$.

\begin{abstract}
While antimicrobial resistance (AMR) is seen in both Neisseria gonorrhoeae and Neisseria meningitidis, the former has become resistant to commonly available over-the-counter antibiotic treatments. It is imperative then to develop new therapies that combat current AMR isolates whilst also circumventing the pathways leading to the development of AMR. This review highlights the growing research interest in developing anti-virulence therapies (AVTs) which are directed towards inhibiting virulence factors to prevent infection. By targeting virulence factors that are not essential for gonococcal survival, it is hypothesized that this will impart a smaller selective pressure for the emergence of resistance in the pathogen and in the microbiome, thus avoiding AMR development to the anti-infective. This review summates the current basis of numerous anti-virulence strategies being explored for N. gonorrhoeae.
\end{abstract}

Keywords: Neisseria gonorrhoeae; antimicrobial resistance; sexually transmitted infections; virulence factors; anti-virulence therapy

\section{Introduction}

Neisseria gonorrhoeae is a Gram-negative diplococcus which causes the sexually transmitted infection (STI) gonorrhea. The World Health Organization (WHO) estimates that of the 376 million new cases per annum of treatable STIs (chlamydia, gonorrhea, syphilis and trichomoniasis), N. gonorrhoeae caused 87 million cases globally [1]. Specifically, in the United States, gonorrhea is the second most commonly reported notifiable infection. A 2018 surveillance report by the Centers for Disease Control and Prevention determined that a total of 583,405 cases had been recorded, an $82.6 \%$ increase from the historic low observed in 2009 [2]. A study on the total lifetime direct medical cost of gonorrhea infections on the US healthcare system was approximately $\$ 81.1$ to $\$ 243.2$ million [3]. However, this cost does not reflect the true economic burden of $N$. gonorrhoeae infections since it did not include costs associated with adverse pregnancy outcomes, disease prevention or productivity loss.

N. gonorrhoeae most commonly colonizes the genital mucosa, but can also colonize the ocular, nasopharyngeal and anal mucosa. Gonococcal infections in men are predominantly symptomatic, but pharyngeal and rectal infections in men are overwhelmingly asymptomatic. Symptomatic patients usually present with acute urethritis, displaying symptoms of dysuria and urethral discharge [4-8]. On the other hand, infections in women 
are frequently asymptomatic, with some studies indicating up to $70 \%$ asymptomatic infection rates [9]. Symptomatic infections of the genital mucosa usually manifest as cervicitis, urethritis and occasionally as pelvic inflammatory disease (PID) [10]. Asymptomatic cases are reservoirs that promote gonorrhea transmission, and undetected AMR strains from these reservoir sites may promote the spread of resistance.

Gonococcal urethritis significantly increases the risk of acquiring and transmitting HIV, thus substantially contributing to the public health burden of this infection [11-15]. Genital infections in pregnant women can have adverse effects on the fetus including spontaneous preterm birth, chorioamnionitis, low birth weight, premature rupture of membranes and spontaneous abortion [16,17]. Additionally, transmission to the neonate may occur during passage through the birth canal. The effects of gonococcal disease for neonates include severe eye infections and bacteremia that can lead to ulceration of the cornea, perforation of the globe of the eyes or permanent blindness [18-21].

To date, no successful vaccine strategies have been developed for gonorrhea in humans, as individuals can contract the disease multiple times throughout their lifetime, suggesting that there is no natural immunity and therefore correlates of protection to benchmark vaccine efficacy [22,23]. Recent studies have observed an association of reduced prevalence of gonorrhea in individuals who have received the N. meningitidis serogroup B vaccine Bexsero ${ }^{\circledR}$, suggesting that there may be cross-protective immunological responses elicited from common antigens in the meningococcal outer membrane (OM) vesicle component [24,25]. Further work is required to fully analyze the immune response elicited by this vaccine, but this provides a framework for future gonococcal vaccines, and reinforces the requirement for human clinical trials to identify successful vaccine antigens [26].

\section{Treatment and Antimicrobial Resistance}

All gonococcal infections are treated with antibiotics, but different regimes may be recommended depending on the site of infection. For urethral, anorectal and oropharyngeal infections, the WHO recommends a dual therapy of $250 \mathrm{mg}$ of intramuscular ceftriaxone as a single dose and $1 \mathrm{~g}$ of oral azithromycin as a single dose [27]. Alternatively, $400 \mathrm{mg}$ of oral cefixime can be administered as a single dose in conjunction with a single $1 \mathrm{~g}$ dose of oral azithromycin. The dual therapy treatment for gonococcal infections is designed to prevent the ever-increasing levels of antibiotic resistance observed in $N$. gonorrhoeae. Neonatal gonococcal conjunctivitis should be treated with $50 \mathrm{mg} / \mathrm{kg}$ intramuscular ceftriaxone as a single dose, $25 \mathrm{mg} / \mathrm{kg}$ intramuscular kanamycin as a single dose or $25 \mathrm{mg} / \mathrm{kg}$ intramuscular spectinomycin as a single dose [27]. Ocular prophylaxis after birth should also be applied to infants following perinatal cervical exposure using topical treatments such as tetracycline hydrochloride or erythromycin eye ointment [28].

It is of great concern that AMR has risen to the point where there now exists no known class of antibiotics to which resistance has not been identified [29-40]. The cost of healthcare treatment for AMR infections is higher than for common infections since patients often have extended hospital stays, and require more intensive and expensive care [41-45].

Development of antibiotics against AMR N. gonorrhoeae has been underway for some time and many clinical candidates such as solithromycin, zoliflodacin, SMT-571 and gepotidacin have entered clinical evaluation for treating uncomplicated gonorrhea [46-50]. Unfortunately, mechanisms for resistance against these antimicrobials are already present in the bacterial population as the targets chosen are not novel. In addition, the suitability of some of these compounds to treat gonorrhea has been reduced due to pharmacological issues such as longevity and stability in the urogenital compartment. There also reports of higher rates of oropharyngeal antibiotic treatment failures compared to other infection sites which have been attributed to the inability of the antibiotic(s) to reach a sufficiently high concentration in the oropharyngeal region [51,52]. Several studies by Chow et al. [53-55] that looked into the effectiveness of antibacterial mouthwash in treating oropharyngeal gonorrhea among men who have sex with men were unsuccessful or halted early due to 
high treatment failure rates, indicating the potential hurdle which oral treatments will have to overcome to reach gonococci present in the oropharynx.

\section{Pathogenesis Mechanisms of N. gonorrhoeae}

Following transmission from an infected to uninfected host, the gonococcus adheres to the apical side of the epithelial cells. This is mediated through gonococcal surface structures such as type IV pili (tfp), opacity (Opa) proteins, lipooligosaccharide (LOS) and the major OM protein porin, PorB [56]. Tfp, LOS and Opa can undergo both phase and antigenic variation during infection that minimizes recognition and elimination by the immune system [57].

Primary attachment is initiated by tfp which bind to the host cell surface receptor CD46 and/or complement receptor $3[58,59]$. In vitro studies indicate that antigenic variation of tfp influences pilus-mediated adherence to human tissue, colony morphology and DNA transformation efficiency $[60,61]$. To promote further intimate attachment, Opa proteins, which are phase variable [62], adhere to the carcinoembryonic antigen-related cell adhesion molecule (CEACAM) receptors, but some variants can bind to heparan sulfate proteoglycans (HSPGs) on host cells [58,63-66]. Attachment is also mediated by gonococcal LOS, which binds specifically to the host asialoglycoprotein receptor on HepG2 cells [67], human sperm cells [68] and epithelial cells [69]. Following adhesion, N. gonorrhoeae replicates to form microcolonies and biofilms $[70,71]$, and some bacteria can proceed to invade epithelial cells by transcytosis [72-74]. During infection, gonococci releases fragments of bacterial LOS, peptidoglycan (PG) and OM vesicles during cell growth that activate two pattern recognition receptors, toll-like receptor (TLR) and nucleotide-binding oligomerization domain-like receptor (NOD) on epithelial cells, macrophages and dendritic cells [75-79]. N. gonorrhoeae also releases heptose-1,7-bisphosphate, a precursor for the incorporation of heptose into LOS, which activates TNF receptor-associated factor-interacting protein with forkhead-associated protein A (TIFA)-dependent immunity [80,81]. Activation of these TIFA, NOD and TLR signaling pathways leads to the activation of inflammatory transcription factors and release of pro-inflammatory cytokines and chemokines (e.g., IL-6, IL-8, CXCL3, CXCL10 and TNF- $\alpha)[58,82,83]$. In response to these signals, large amounts of polymorphonuclear leukocytes (PMNs) are recruited to the site of infection, where $N$. gonorrhoeae is recognized and phagocytosed. Since gonococci can survive and replicate within PMNs, the massive influx of PMNs forms an observable purulent exudate that facilitates transmission [84].

\section{Resistance of Gonococcus to Killing by Macrophages and PMNs}

$N$. gonorrhoeae can avoid clearance by the immune system through a variety of mechanisms, including manipulating phagocytosis, modulation of the oxidative burst, defending against toxic neutrophil products and extending the neutrophil lifespan. Macrophages and PMNs are both phagocytic cells which utilize oxidative and non-oxidative mechanisms in microbial killing and degradation $[85,86]$.

N. gonorrhoeae has four major mechanisms through which it is resistant to reactive oxygen species (ROS): quenching ROS, detoxification of ROS, maintaining redox homeostasis, and repair of oxidative damage. ROS can be quenched through a manganese (Mn) uptake system that uses $\mathrm{Mn}(\mathrm{II})$, encoded by the gene locus $m n t A B C$ [87-89]. Detoxification of ROS occurs primarily through the expression of a cytoplasmic catalase, kat $A$ [90]. Additionally, N. gonorrhoeae can also maintain redox homeostasis through the production of glutathione, encoded by gor [91], while superoxide resistance is mediated by the periplasmic antioxidant Sco [92]. Finally, N. gonorrhoeae can protect nucleic acids from ROS through recombination repair mechanisms. It has been shown that several enzymes, including RecA, members of the Ref-like and RecBCD pathways, and Holliday junction resolvases RuvAC and RecF, all contribute to gonococcal survival after exposure to ROS [93]. Other enzymes such as RecN, PriA (replication restart enzyme), UvrABCD (nucleotide excision repair system), and MsrA/B have all been implicated in repair of oxidative damage [94,95]. 
Multiple mechanisms are employed by the gonococcus to evade the non-oxidative killing mechanisms of macrophages and PMNs. Phosphoethanolamine (pEtN) modification and sialylation of LOS results in increased resistance of bacteria to antimicrobial components, such as cationic antimicrobial peptide (CAMP) LL-37, while pili and porins have been reported to inhibit the release of antimicrobial substances [96]. Zughaier et al. (2015) [83] showed that pEtN modification of the lipid A moiety of the LOS reduced autophagy pathways in RAW 264.7 murine and human THP-1 macrophages. Additionally, the modulation of cellular iron metabolism has been reported to facilitate the survival of bacteria inside macrophages [97]. Gonococci have also been known to suppress immunity by polarizing macrophages and upregulating inflammatory and immunosuppressive cytokines (IL-6 and IL-10, respectively) [98]. The efflux pump systems have been shown to protect bacteria against the killing mechanisms of immune cells. The Mtr (multiple transferrable resistance) efflux pump system, MtrCDE, plays an important role in enhancing gonococcal survival during vaginal tract infection in mice models [99]. This efflux system also contributes towards extracellular survival, PMN extracellular traps and to PMN-derived antimicrobial peptides [100]. FarAB, another efflux system, also exports host-derived antimicrobials, but the exact mechanism of how this system contributes to bacterial defense against immune cells remains unknown [99].

\section{AVTs as an Intervention Strategy}

Antibiotic resistance in bacteria is driven by exposure to antibiotics. This exposure can occur via the food chain which delivers subtherapeutic concentrations of drug in the diet that drive the development of resistance in the microbiome. During antibiotic treatment of acute symptomatic infections [101,102], the majority of the human microbiome is removed, leaving resistant strains to proliferate and donate genetic markers of resistance via horizontal transfer mechanisms to colonizing pathogens (Figure 1A). In the case of $N$. gonorrhoeae, resistance markers evolve in the commensal Neisseria species of the human microbiome or in response to repeated antibiotic treatment failures. As this genus is naturally transformable, the pathogenic gonococci acquire the genetic markers via transformation and homologous recombination, in addition to in situ evolution of mutations in antibiotic target genes [103-105].

A
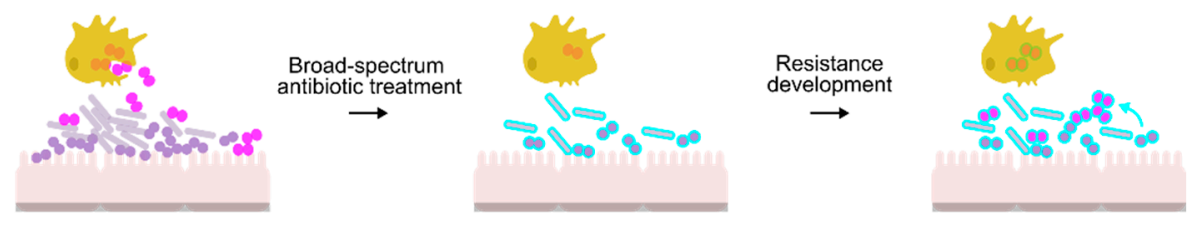

B
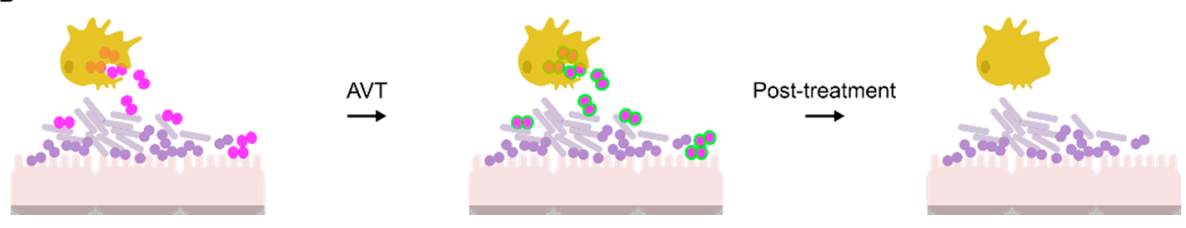

Figure 1. Comparison of antibiotic and anti-virulence approaches for treatment of N. gonorrhoeae. (A) Potential route for antibiotic resistance development in N. gonorrhoeae (pink diplococci). Antibiotics also affect the microbiome (Lactobacilli: grey rods; commensal Neisseria: purple circles), forcing resistance determinants to evolve (blue outline). This resistance can then develop in N. gonorrhoeae through gene acquisition via natural transformation (blue arrow) or spontaneous mutation. While antibiotic treatment may assist PMNs and macrophages (yellow cells) in killing the bacteria, the prescribed concentration may not be effective, resulting in proliferation of antibiotic resistant bacteria. (B) Use of AVTs (green outline) enables PMNs and macrophages to kill the gonococci without affecting the microbiome. 
Anti-virulence therapies (AVTs) are compounds that target virulence pathways required for microbial pathogenesis in the host but are not essential to the growth of the pathogen in standard laboratory conditions [106]. Tailoring the AVT towards targets unique to the pathogen reduces selective pressure on the commensal flora, which remains intact and therefore is unable to become a reservoir of resistance determinants (Figure 1B). In the specific case of $N$. gonorrhoeae, preservation of the vaginal microbiome could also protect against gonococcal re-infection [107].

\section{Gonococcal Virulence Factors as Targets for Inhibitor Design}

An ideal anti-virulence target should be found in all disease-causing strains and be essential for pathophysiology. Multiple compartments within the bacterial cell, including the cell wall, OM and secreted components fit these criteria (Table 1) and are summarized in Figure 2. Known anti-virulence targets and drug discovery programs against gonococcal virulence factors are explained in detail in the following sections.

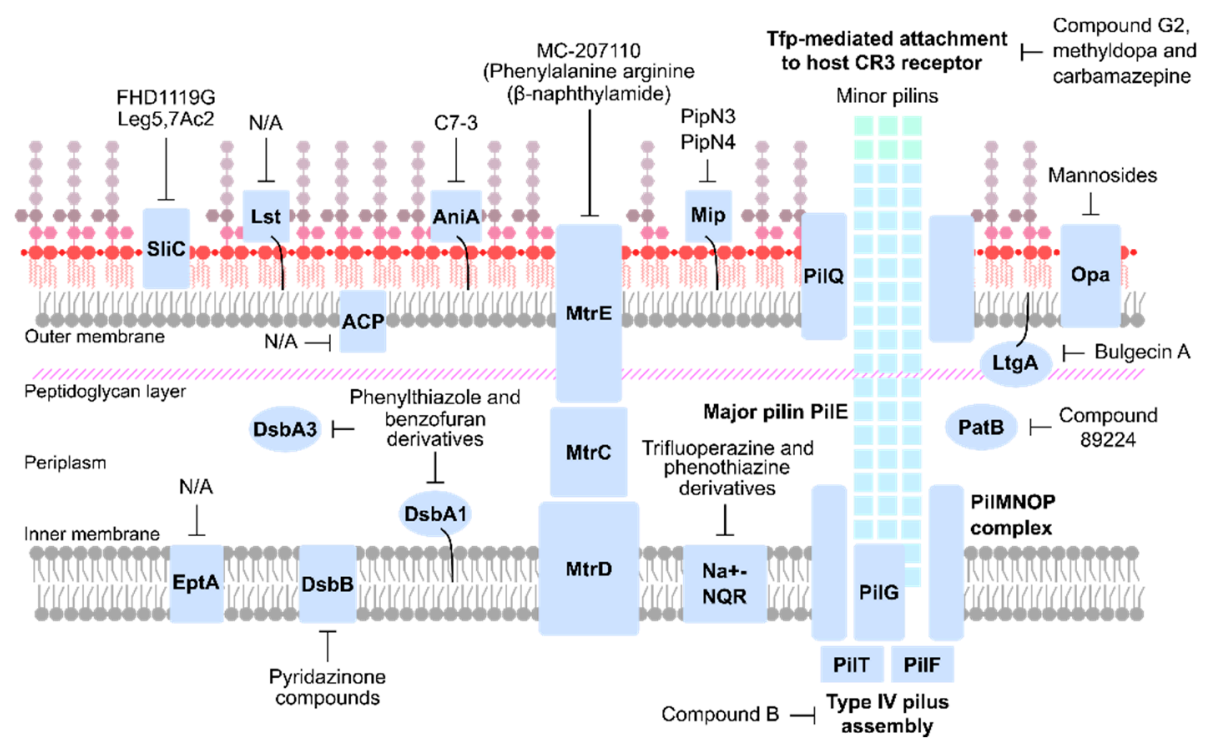

Figure 2. Overview of anti-virulence therapeutic targets of N. gonorrhoeae.

\subsection{Bacterial Cell Wall Maintenance and Modification}

The gonococcal cell wall is characterized by the presence of both an inner membrane (IM) and OM separated by a PG layer. The PG is made up of linear glycan strands (repeating units of alternating $N$-acetylmuramic acid and $N$-acetylglucosamine residues joined through $\beta-1,4$ glycosidic bonds) cross-linked by short peptides [194-196]. The outer leaflet of the neisserial OM is composed of LOS, which consists of a membrane-anchoring lipid A domain and an inner core of 3-deoxy-D-manno-2-octulosonic acid linking it to a polysaccharide core [197]. Lipid A comprises a di-glucosamine backbone, 1- and 4'phosphate groups and six acyl chains [198,199]. Since the PG and OM provide a substantial protective barrier, targeting enzymes that preserve or remodel the PG, such as acetylases and lysozyme inhibitors [121,122,124,200], and LOS components could represent promising novel drug targets for treating MDR gonococcal infections. 
Table 1. Summary of anti-virulence targets in N. gonorrhoeae.

\begin{tabular}{|c|c|c|c|c|c|c|c|}
\hline \multirow{2}{*}{$\begin{array}{c}\text { Anti- } \\
\text { Virulence } \\
\text { Target }\end{array}$} & \multirow{2}{*}{ Function } & \multicolumn{3}{|c|}{ Target Validation } & \multirow{2}{*}{$\begin{array}{l}\text { Available } \\
\text { Inhibitors }\end{array}$} & \multirow{2}{*}{ Inhibitor Studies } & \multirow{2}{*}{ References } \\
\hline & & In Vitro Testing & Structural Studies & In Vivo Models & & & \\
\hline \multicolumn{8}{|c|}{ Bacterial cell wall maintenance and modification } \\
\hline EptA & $\begin{array}{l}\text { Catalyzes the } \\
\text { addition of pEtN } \\
\text { onto lipid A of the } \\
\text { OM. }\end{array}$ & $\begin{array}{l}\text { Loss of EptA } \\
\text { increases } \\
\text { susceptibility to } \\
\text { killing by PMNs, } \\
\text { macrophages, } \\
\text { CAMPs and human } \\
\text { serum. }\end{array}$ & $\begin{array}{l}\text { Full structure solved of } N \text {. } \\
\text { meningitidis homologue ( } 98 \% \\
\text { identity, PDB } \\
\text { accession code 5FGN). }\end{array}$ & $\begin{array}{c}\text { Reduced survival } \\
\text { rates of ept } A \text { mutant } \\
\text { in mouse and human } \\
\text { models. }\end{array}$ & $\mathrm{N} / \mathrm{A}$ & $\mathrm{N} / \mathrm{A}$ & {$[83,108-112]$} \\
\hline Lst & $\begin{array}{c}\text { Catalyzes the } \\
\text { addition of } \\
N \text {-acetyl-neuraminic } \\
\text { acid onto } \\
\text { lacto- } N \text {-neotetraose } \\
\text { of LOS. Primary } \\
\text { mechanism for } \\
\text { resistance to human } \\
\text { complement. }\end{array}$ & $\begin{array}{l}\text { Loss of Lst increases } \\
\text { susceptibility to } \\
\text { killing by PMNs and } \\
\text { human serum. }\end{array}$ & $\begin{array}{l}\text { Full structure of } N \text {. meningitidis } \\
\text { homologue apo form }(92 \% \\
\text { identical, PDB accession code } \\
\left.2 \mathrm{YK} 4^{1}\right) \text { and with structural } \\
\text { donor sugar analogs or } \\
\text { products solved (PDB } \\
\text { accession code } 2 \mathrm{YK} 5,2 \mathrm{YK} 6 \text {, } \\
\left.\text { and } 2 \mathrm{YK}^{1}\right) \text {. }\end{array}$ & $\begin{array}{l}\text { Reduced survival } \\
\text { rates of } l s t \text { mutant in } \\
\text { mouse models. }\end{array}$ & $\begin{array}{l}\text { FHD1119G and } \\
\text { Leg5,7Ac } 2\end{array}$ & $\begin{array}{l}\text { Increased serum } \\
\text { sensitivity. Significantly } \\
\text { reduced duration and } \\
\text { burden of infection in } \\
\text { mouse vaginal } \\
\text { colonization model. }\end{array}$ & [113-119] \\
\hline $\begin{array}{l}\text { NgACP and } \\
\text { SliC }\end{array}$ & $\begin{array}{l}\text { Essential for } \\
\text { survival against } \\
\text { lysozyme. }\end{array}$ & $\begin{array}{l}\text { Loss of } \mathrm{NgACP} \text { and } \\
\text { SliC increased } \\
\text { susceptibility to } \\
\text { human lysozyme. } \\
\text { NgACP loss } \\
\text { significantly reduced } \\
\text { survival in PMNs. }\end{array}$ & $\begin{array}{c}\text { Mature NgACP structure has } \\
\text { been solved (PDB } \\
\text { accession code 6GQ4). } \\
\text { Structure of SliC homologue in } \\
\text { Pseudomonas aeruginosa (MliC) } \\
\text { solved ( } 23.3 \% \text { identity, PDB } \\
\left.\text { accession code } 3 \mathrm{~F}^{1} \mathrm{Z}^{1}\right) .\end{array}$ & $\begin{array}{l}\text { Reduced survival } \\
\text { rates of sliC mutant } \\
\text { in mouse models. }\end{array}$ & $\mathrm{N} / \mathrm{A}$ & $\mathrm{N} / \mathrm{A}$ & [120-123] \\
\hline PatB & $\begin{array}{c}\text { Catalyzes } \\
\text { O-acetylation of } \\
N \text {-acetyl-muramic } \\
\text { acid. }\end{array}$ & $\begin{array}{l}\text { Increased sensitivity } \\
\text { to lysozyme in } \\
\text { human sera or } \\
\text { lysozyme purified } \\
\text { from human PMNs. }\end{array}$ & $\begin{array}{c}\text { Structure of PatB homologue } \\
\text { in } \\
\text { Staphylococcus aureus (OatA } \\
\text { C-terminal catalytic domain) } \\
\text { has been solved (15\% identical, } \\
\text { PDB } \\
\left.\text { accession code } 6 \mathrm{VJP}^{1}\right) \text {. }\end{array}$ & $\mathrm{N} / \mathrm{A}$ & Compound 89224 & $\begin{array}{c}\text { Treatment reduced } \\
\text { bacterial growth by } 90 \% \text {. } \\
\text { Inhibitor binding studied } \\
\text { using microtiter } \\
\text { plate-based fluorometric } \\
\text { assay. }\end{array}$ & [124-131] \\
\hline
\end{tabular}


Table 1. Cont.

\begin{tabular}{|c|c|c|c|c|c|c|c|}
\hline \multirow{2}{*}{$\begin{array}{c}\text { Anti- } \\
\text { Virulence } \\
\text { Target }\end{array}$} & \multirow{2}{*}{ Function } & \multicolumn{3}{|c|}{ Target Validation } & \multirow{2}{*}{$\begin{array}{l}\text { Available } \\
\text { Inhibitors }\end{array}$} & \multirow{2}{*}{ Inhibitor Studies } & \multirow{2}{*}{ References } \\
\hline & & In Vitro Testing & Structural Studies & In Vivo Models & & & \\
\hline \multicolumn{8}{|c|}{ Bacterial cell wall maintenance and modification } \\
\hline $\operatorname{Ltg} \mathrm{A}$ & $\begin{array}{l}\text { Catalyzes cleavage of } \\
N \text {-acetyl-muramic } \\
\text { acid- } \beta-1,4-N- \\
\text { acetylglucosamine to } \\
\text { form PG monomer } \\
\text { fragments during cell } \\
\text { growth. }\end{array}$ & $\begin{array}{l}\text { Reduction in PG } \\
\text { monomer release. } \\
\text { Loss of LtgA in } N \text {. } \\
\text { meningitidis has a } \\
\text { detrimental effect on } \\
\text { bacterial cell growth, } \\
\text { division, and } \\
\text { separation. }\end{array}$ & $\begin{array}{l}\text { Structure of } N \text {. meningitidis } \\
\text { homologue }(97 \% \text { identical, } \\
\left.\text { PDB accession code } 6 \mathrm{FPN}^{1}\right) \text {. }\end{array}$ & $\begin{array}{l}N m L \operatorname{LA} \text { A mutant } \\
\text { cleared quicker than } \\
\text { wild-type and } \\
\text { reduced cytokine } \\
\text { induction in mouse } \\
\text { model. }\end{array}$ & Bulgecin A & $\begin{array}{c}\text { Inhibited LgtA activity and } \\
\text { had a synergistic effect } \\
\text { with } \beta \text {-lactams. }\end{array}$ & {$[75,132-137]$} \\
\hline \multicolumn{8}{|c|}{ Anaerobic survival } \\
\hline AniA & $\begin{array}{l}\text { Reduces nitrite to } \\
\text { nitric oxide. Essential } \\
\text { for anaerobic growth. }\end{array}$ & $\begin{array}{l}\text { Loss of AniA } \\
\text { reduces anaerobic } \\
\text { growth and biofilm } \\
\text { formation. }\end{array}$ & $\begin{array}{c}\text { Soluble domain structure } \\
\text { solved (PDB accession code } \\
\text { 1KBW, 1KBV, 5TB7, and } \\
\text { 5UE6). }\end{array}$ & $\begin{array}{l}\text { Immunization with a } \\
\text { truncated form of } \\
\text { AniA generates } \\
\text { protective antisera in } \\
\text { a mouse model. }\end{array}$ & C7-3 & $\begin{array}{l}\text { Significantly inhibited } \\
\text { enzyme activity and } \\
\text { gonococcal growth } \\
\text { under anaerobic } \\
\text { conditions. Inhibitor } \\
\text { binding studied using } \\
\text { molecular docking and } \\
\text { biolayer interferometry. } \\
\text { A patent has been } \\
\text { approved for C7-3 and its } \\
\text { derivatives. }\end{array}$ & [138-142] \\
\hline
\end{tabular}


Table 1. Cont.

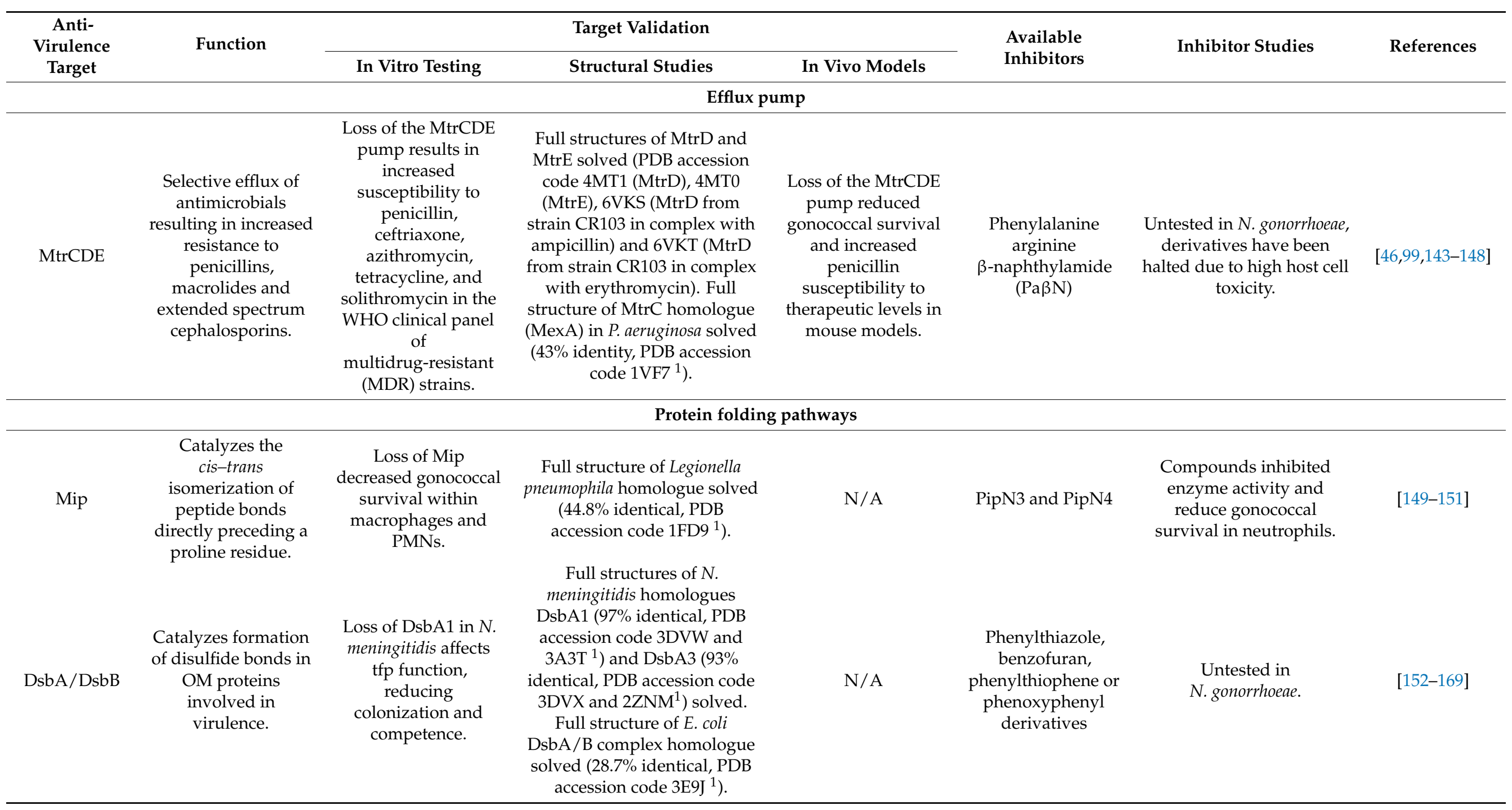


Table 1. Cont

\begin{tabular}{|c|c|c|c|c|c|c|c|}
\hline \multirow{2}{*}{$\begin{array}{c}\text { Anti-Virulence } \\
\text { Target }\end{array}$} & \multirow{2}{*}{ Function } & \multicolumn{3}{|c|}{ Target Validation } & \multirow{2}{*}{ Available Inhibitors } & \multirow{2}{*}{ Inhibitor Studies } & \multirow{2}{*}{ References } \\
\hline & & In Vitro Testing & Structural Studies & In Vivo Models & & & \\
\hline \multicolumn{8}{|c|}{ Adhesion and invasion } \\
\hline Type IV pili & $\begin{array}{l}\text { Essential for adhe- } \\
\text { sion/colonization, } \\
\text { horizontal gene } \\
\text { transfer, twitching } \\
\text { motility. }\end{array}$ & $\begin{array}{l}\text { Tfp mutants lacking } \\
\text { PilE are unable to } \\
\text { adhere to human } \\
\text { epithelial cells, are } \\
\text { non-motile and are } \\
\text { incompetent. }\end{array}$ & $\begin{array}{c}\text { Tfp structure has been } \\
\text { solved (PDB accession } \\
\text { code 5VXX, 1AY2, 2HIL } \\
\text { and 2HI2). }\end{array}$ & $\begin{array}{l}\text { In the human male } \\
\text { model of infection, } \\
\text { men inoculated with } \\
\text { a gonococcal pile } \\
\text { mutant developed } \\
\text { watery urethral } \\
\text { discharge or were } \\
\text { asymptomatic. }\end{array}$ & $\begin{array}{l}\text { Compound B } \\
\text { Phenothiazines }\end{array}$ & $\begin{array}{l}\text { Prevents pilus elongation. } \\
\text { Inhibited } \mathrm{Na}^{+} \text {-pumping } \\
\text { NADH:quinone } \\
\text { oxidoreductase. Tests with } \\
\text { N. meningitidis reduced } \\
\text { bacteremia and increased } \\
\text { survival in a mouse model. } \\
\text { Inhibits tfp binding to host } \\
\text { receptor CR3 on primary } \\
\text { cell line. Carbamazepine } \\
\text { and methyldopa are } \\
\text { re-purposed drug } \\
\text { (FDA-approved } \\
\text { anti-convulsant and high } \\
\text { blood pressure medication, } \\
\text { respectively). }\end{array}$ & [170-183] \\
\hline $\begin{array}{l}\text { Mannose- } \\
\text { binding (Opa) } \\
\text { proteins }\end{array}$ & $\begin{array}{l}\text { Required for } \\
\text { adherence to host } \\
\text { epithelial cells. }\end{array}$ & $\begin{array}{l}\text { Opa-less bacteria do } \\
\text { not adhere to } \\
\text { Chinese hamster } \\
\text { ovary cells. }\end{array}$ & $\begin{array}{l}\text { Structure of Opa60 has } \\
\text { been solved }(76 \% \\
\text { identity, PDB accession } \\
\left.\text { code } 2 \mathrm{MAF}^{1}\right) .\end{array}$ & $\begin{array}{c}\text { Gonococci recovered } \\
\text { from human models } \\
\text { are always Opa } \\
\text { positive, even if the } \\
\text { inoculum was Opa } \\
\text { negative. }\end{array}$ & $\begin{array}{l}\text { ConA and } \alpha \text {-methyl } \\
\text { D-mannoside } \\
\text { (Mannosides) }\end{array}$ & $\begin{array}{l}\text { Compounds reduced } \\
\text { gonococcal adherence to } \\
\text { primary cervical epithelial } \\
\text { cells and urethral epithelial } \\
\text { cells. }\end{array}$ & [184-190] \\
\hline
\end{tabular}

${ }^{1}$ PDB identification and percentage identity obtained using the NCBI BLASTp query of the PDB database [191-193]. 


\subsubsection{Lipid A Phosphoethanolamine Transferase}

The modification of lipid A with pEtN is mediated by the enzyme lipid A phosphoethanolamine transferase (EptA). EptA adds pEtN to the 1 and/or $4^{\prime}$ positions of lipid A $[108,201]$ and is a characteristic virulence factor of pathogenic Neisseria [202] that affects multiple aspects of gonococcal survival. The presence of the positively charged $\mathrm{pEtN}$ affects the neisserial cell surface and gonococcal strains lacking pEtN modification have been proven to be more susceptible to CAMPs and complement-mediated killing $[109,203,204]$. In addition, further studies have shown that ept $A$ knockout strains are highly susceptible to killing by human PMNs and macrophages $[83,111]$. Loss of $\mathrm{pEtN}$ decoration was also found to decrease binding of LOS by the host TLR-4/MD-2 signaling pathway and lower cytokine expression $[77,202]$. EptA is also essential for survival in the murine female genital tract and in human male volunteers. A study by Hobbs et al. (2013) [110] showed that in competitive inhibition assays in mice, there was a minimum of 10-10,000-fold reduction in ept $A$ mutant strain recovery compared to the wild type. No ept $A$ mutant strains could be recovered after day 6 post-inoculation in mice, and in human volunteers, ept $A$ mutants could not be recovered at any point in time post-inoculation.

The enzyme EptA is a particularly attractive target as it is essential for pathogenesis, is the only lipid A-modifying enzyme present and is found in all strains of pathogenic Neisseria. While there are no studies currently published on the development of inhibitors targeting EptA, this enzyme is a promising target for structure-based drug design. Crystallographic and functional studies have highlighted residues in the catalytic site where inhibitors can be designed to target, thereby reversing the resistance of the gonococci to antimicrobial peptides $[112,201,205,206]$.

\subsubsection{LOS Sialyltransferase}

The $\alpha$-chain of LOS is variable due to the differing expression of LOS glycosyltransferases (Lgt), which sequentially add glycan residues to the $\alpha$-chain extending from HepI [207]. The expression of certain $\alpha$-chain structures which mimic host glycans, such as lacto- $N$-neotetraose (LNT), play an important role in attachment to and invasion of the host epithelium and immune invasion in both gonococci and N. meningitidis [63,208]. In particular, the sialylation of gonococcal LNT with sialic acid (Neu5Ac) by LOS sialyltransferase (Lst) has been shown to confer serum resistance when grown in media supplemented with cytidine monophospho- $N$-acetylneuraminic acid (CMP-NANA, the donor molecule for Neu5Ac) [209-213] by interfering with all three complement activation pathways [213-216]. The lst gene is ubiquitous among gonococcal isolates [217], and is actively expressed following contact with host cells under the control of the transcriptional regulator CrgA [218], making it an attractive potential target for anti-virulence therapies [219].

Two major anti-virulence strategies targeting LOS sialylation have been investigated to date. One strategy made use of chimeric proteins consisting of factor $\mathrm{H}$ linked to the $\mathrm{Fc}$ domain of murine IgG-termed FH/Fc [117]. By mimicking factor $\mathrm{H}$ mutations observed in atypical hemolytic uremic syndrome (a condition resulting in the overactivation of the alternative complement pathway), Shaughnessy and colleagues created a variant of FH/Fc, FHD1119G, which was non-toxic to host cells but could bind to multiple sialylated clinical isolates of $N$. gonorrhoeae, including ceftriaxone-resistant isolates, to varying degrees. FHD1119G was also shown to have a bactericidal activity of $>50 \%$ in 10 of the 15 isolates studied and could increase C3 deposition on the remaining five strains which resisted direct killing. In a mouse vaginal colonization model, FHD1119G reduced the bacterial load over the course of the infection and the median time to clearance from 7 to 5 days.

The second anti-virulence strategy targeting gonococcal LOS sialylation makes use of analogues of CMP-NANA, such as Leg5,7Ac 2 and Neu5Ac9 $\mathrm{N}_{3}$ (collectively termed CMP-nonulosonates or CMP-NulOs). When grown in the presence of CMP-NulOs, these analogues were successfully incorporated into gonococcal LOS by Lst without conferring resistance to complement mediated killing [116]. Further investigation revealed that Leg5,7 $\mathrm{Ac}_{2}$ reduced factor $\mathrm{H}$ binding to levels equivalent to unsialylated gonococci, reduced 
clearance time of gonococcal infections in mice, and was able to block serum resistance even when added to the medium following the addition of CMP-NANA [118]. Leg5,7Ac 2 was also shown to not be incorporated onto the surface of human B lymphoma cells, indicating that it may potentially be safe for use in humans [118]. Interestingly, the main mechanism by which CMP-NulOs provide protection in mouse models is by protecting against cathelicidins, not by inducing resistance to complement [119].

Several obstacles to the use of anti-sialic acid-based therapeutics exist. Sialidases expressed by the microbial flora of the vagina may de-sialylate gonococcal LOS, rendering $\mathrm{FH} / \mathrm{Fc}$ based approaches ineffective [219]. Differences in the interaction of gonococci with the male and female genital tracts may also affect the efficacy of potential therapies [63].

\subsubsection{Lysozyme Inhibitors}

The location of gonococcal colonization (e.g., urethra, pharynx, rectum, cervix, and conjunctiva) is rich in lysozyme, produced as part of the innate immune system or in macrophages, neutrophils, and dendritic cells [220-223]. Lysozyme is an antimicrobial protein that causes cell lysis and death through glycosidic bond hydrolysis between the carbohydrate motifs that make up the PG layer [224,225].

$N$. gonorrhoeae encodes two direct lysozyme inhibitors, surface-exposed lysozyme inhibitor of c-type lysozyme (SliC) and N. gonorrhoeae-adhesin complex protein (NgACP) [121,122]. The expression of these inhibitors is upregulated and essential for survival when exposed to lysozyme. In the study by Ragland et al. (2018) [121], mutants lacking either SliC, $\mathrm{NgACP}$ or both were constructed and tested against lysozyme from a variety of sources (i.e., human lysozyme, pooled human tears or pooled human saliva, and neutrophils). The loss of $\mathrm{NgACP}$ resulted in a significantly reduced gonococcal survival when exposed to lysozyme or neutrophils which SliC alone could not compensate for. However, these in vitro experiments did highlight the importance of both inhibitors in lysozyme resistance as the double mutant exhibited an increased sensitivity to lysozyme over either single mutant. SliC was found to play an important role in vivo survival as shown through experimental infection of female mouse genital tract. Mice infected with a strain lacking SliC resulted in a 3-, 372-, and 198-fold lower recovery than the wild-type strain on days 1, 3 , and 5 post-inoculation. The same experiment in lysozyme defective mice supported the importance of SliC during in vivo infection.

Both SliC and $\mathrm{NgACP}$ are attractive targets for anti-virulence therapy and as potential vaccine candidates due to their extracellular localization, expression during human infection, and relative conservation among gonococcal strains $[123,226,227]$. No studies have yet to be published regarding the development of inhibitors or vaccine trials using SliC and $\mathrm{NgACP}$ but the structure of $\mathrm{NgACP}$ has been solved [123] and can be used to pursue structure-based drug design.

\subsubsection{PG O-Acetyltransferase B}

Similar to the lysozyme inhibitors $\mathrm{NgACP}$ and SliC, the enzyme PG O-acetyltransferase $\mathrm{B}$ (PatB) provides protection against lysozyme-induced lysis. In addition, it plays a role in regulating gonococcal cell autolysis by preventing PG degradation. PatB is hypothesized to function together with PatA (an integral IM protein) as a two component system, whereby PatA translocates the presumed substrate acetyl-CoA to PatB in the periplasm, which then acts as a substrate for acetyl group addition onto the C-6 hydroxyl group of $\mathrm{N}$ acetylmuramic acid $[124,125,127,128,133,228]$. Preventing $O$-acetylation of PG is key in mitigating the detrimental downstream effects of large circulating gonococcal $O$-acetylated PG fragments, such as arthritis and PG-mediated complement consumption [126,130,229,230] whilst returning sensitivity to lysozymes present in the host immune system. In addition, compounds targeting this enzyme will have the added benefit of not affecting the existing microbiota in the host that do not acetylate their PG.

In the study by Brott et al. (2019) [129], inhibitors were identified using high throughput screening that monitored hydrolysis of a fluorescent substrate, 4-methylumbelliferyl- 
acetate. Following validation pilot screens, optimized screening conditions and stringent statistical parameters were used to eliminate false positives. The remaining 12 compounds were put through dose response assays, followed by fluorescence quenching assays that removed potential hits with chemical properties that interfered with the assay. The compound 89224 was identified as a mixed/non-competitive inhibitor of pat $B$ with a $K_{i}$ of $126 \pm 19.5 \mu \mathrm{M}$. This compound is a benzothiazolyl-pyrazolo-pyridine derivative specific for $\mathrm{O}$-acetylated $\mathrm{PG}$, as evidenced by bacteriostatic growth inhibition of $\mathrm{N}$. gonorrhoeae but not E. coli.

\subsubsection{Lytic Transglycosylase A}

Lytic transglycosylases, in particular lytic transglycosylase A ( LtgA) and LtgD, are involved in PG turnover through the cleavage of the glycosidic bond between $N$-acetylmuramic acid and $N$-acetylglucosamine, which results in the formation 1,6-anhydromuramic acidbased structures [75,132]. LtgA and LtgD are OM proteins, localizing in the cell septum and in discrete focal points around the bacterium, respectively [134]. Loss of LtgA and LtgD results in markedly reduced PG monomer release and increased sensitivity to killing by neutrophils that is independent from monomer release [135]. In N. meningitidis, an LtgA active site mutant strain had a detrimental effect on bacterial cell growth, division, and separation. In an in vivo mouse model, the mutant strain was cleared quicker and had a reduced cytokine production level [137].

The compound bulgecin A was found to bind specifically to a soluble lytic transglycosylase in E. coli and has been shown to have a synergistic effect when used with $\beta$-lactams to cause bulges in the cell wall of a variety of Gram-negative species [231-236]. Williams et al. (2017) investigated the effects of bulgecin A in pathogenic Neisseria in addition to solving the structure of LtgA from N. meningitidis complexed with bulgecin A [136]. The solved complex showed bulgecin A occupying the conserved active site of LtgA, suggesting that it acts as a competitive inhibitor and demonstrated the effect of bulgecin $A$ on the ability of LtgA to facilitate 1,6-anhydro-muropeptide release using in vitro inhibition experiments. This study also demonstrated the synergistic effect of bulgecin A with $\beta$-lactams as seen in the lowered MIC values for penicillin G, amoxicillin and cefotaxime against pathogenic Neisseria.

\subsection{Anaerobic Survival}

Evidence of biofilm formation in cervical infections supports the persistence of gonococcal disease in women as the matrix protects against antibiotics and host defenses $[237,238]$. Due to this matrix, there exists a concentration gradient of oxygen and nutrients, suggesting that the bacteria can grow under anaerobic conditions. Several different genes are upregulated in response to anaerobic growth, including aniA (nitrite reductase) [239] and norB (nitric oxide reductase) [240].

Anaerobically induced protein A (AniA) is the only anaerobically induced OM protein that is undetected during aerobic growth [241] and reduces nitrite to nitric oxide. The presence of antibodies to AniA in the sera of patients diagnosed with gonorrhea or PID strongly suggests that AniA is expressed during pathogenesis [242]. Since AniA is present in all strains of $N$. gonorrhoeae and is essential for the growth and survival of $N$. gonorrhoeae under anaerobic conditions and for biofilm formation, it has become a target for both vaccine and inhibitor studies [23,139-141].

The inhibitor study by Sikora et al. (2017) [141] used a phage display approach to identify ligands interacting with AniA. From a large initial library of peptides, 29 peptides were identified and further examined using an enzyme-linked immunosorbent assay. The results of this assay and computational docking studies revealed that the inhibitor C7-3 was the most promising, binding near the type 2 copper site of the enzyme responsible for interaction with nitrite. Subsequent experiments with C7-3 and its derivatives, C7$3 \mathrm{~m} 1$ and C7-3m2, demonstrated potent inhibition of AniA and antimicrobial activity 
against anaerobically grown $N$. gonorrhoeae strain 1291, which has resulted in potential commercialization of these materials [142].

\subsection{Efflux Pumps}

Most drug efflux proteins belong to five distinct families: the resistance-nodulation-cell division (RND), major facilitator, staphylococcal/small MDR, ATP-binding cassette, and multidrug and toxic compound extrusion families [243]. In gonococci, four efflux pump systems, MtrCDE, MacAB, NorM, and FarAB, have been identified in all strains [244-247]. The MtrCDE system belongs to the RND family and has been shown to recognize antimicrobials previously or currently recommended for gonorrhea treatment [46,248-250].

A major gonococcal AMR determinant is the MtrCDE pump. It is composed of $\mathrm{IM}$ and $\mathrm{OM}$ channels (MtrD and MtrE, respectively), which are connected through a periplasmic membrane fusion lipoprotein (MtrC) [244,251,252]. Expression of $m \operatorname{trCDE}$ is directly regulated by the MtrR repressor and MtrA activator [253-255]. Mutations causing the overexpression of MtrCDE can occur in MtrR or in the promoter region of the $m \operatorname{trCDE}$ operon, conferring increased resistance to antibiotics such as azithromycin [244,248]. Jerse et al. (2003) [99] found that mutations in $m \operatorname{tr} C D E$ reduced gonococcal survival in the female murine genital tract. Additionally, Chen et al. (2019) [147] showed that transcriptional repression of the MtrCDE efflux pump in penicillin resistant strains could increase the penicillin susceptibility to therapeutic levels in mice models. MtrCDE may also contribute to in vivo gonococcal survival by protecting against the antimicrobial effects of fatty acids and CAMPs found at mucosal surfaces $[248,256]$.

Efflux pump inhibitors have been considered for the treatment of gonorrhea for quite some time as $m \operatorname{tr} C D E$ is expressed by gonococci in the human urogenital tract of both men and women [226,257]. However, the current candidates under development such as the efflux pump inhibitor MC-207110 (phenylalanine arginine $\beta$-naphthylamide) have been associated with high levels of host cell toxicity and unfavorable pharmacokinetic properties $[143,145,258]$.

\subsection{Protein Folding Pathways}

The process of protein folding is crucial for ensuring that proper biological activity and conformational stability is achieved as protein misfolding in prokaryotic cells can lead to aggregation into insoluble inclusion bodies [259]. As such, bacteria contain several mechanisms that prevent misfolding from occurring. These molecular chaperones facilitate native protein stabilization, translocation, re-folding, and degradation, and include proteins such as heat-shock proteins [260,261], peptidyl-prolyl cis-trans isomerases (PPIases) [262] and oxidoreductases [152,263].

\subsubsection{Macrophage Infectivity Potentiator}

Macrophage infectivity potentiator (Mip) proteins are members of the FK-506 binding protein subfamily, belonging to the immunophilin superfamily. This protein family exhibits PPIase activity, thereby catalyzing the cis-trans isomerization of peptide bonds directly preceding a proline residue [262]. This is an inherently slow reaction and can be rate limiting in the correct folding of various proteins in the absence of a PPIase protein [264,265].

The Mip protein in N. gonorrhoeae is an OM protein found to be present, with a high degree of similarity, in all 20 clinical strains tested by Starnino et al. (2010) [266]. In addition, all infected patients' sera were able to recognize recombinant $\mathrm{NgMip}$ protein, indicating immunogenicity. This was reinforced by the work of Humbert and Christodoulides (2018) [267] which showed that recombinant N. meningitidis Mip can produce bactericidal antibodies that are effective against both $N$. meningitidis and N. gonorrhoeae strains. Further, a $N$. gonorrhoeae strain lacking $\mathrm{NgMip}$ showed decreased survival within murine RAW 264.7 macrophage cells [150]. The ability of a N. meningitidis strain lacking NmMip to grow in human whole blood was decreased in comparison to the parent control [268]. These data indicate the importance of the Mip protein in the virulence of pathogenic Neisseria species. 
Novel inhibitors originally designed against the Mip protein of Legionella pneumophila and Burkholderia pseudomallei were tested against $N$. gonorrhoeae and N. meningitidis by Reimer et al. (2016) [151]. The cognate inhibitor of Mip proteins, rapamycin, was used as a basis for the synthesis of these pipecolic acid derivative inhibitors, and the high level of conservation of Mip proteins across bacterial species allowed for successful screening across multiple pathogens. The two inhibitors studied, PipN3 and PipN4, were able to inhibit the PPIase activity of recombinant gonococcal Mip, as well as reduce intracellular survival of N. gonorrhoeae in PMNs. Treatment with PipN3 and PipN4 also reduced the ability of $N$. meningitidis to adhere to and invade human nasopharyngeal Detroit 562 epithelial cells.

\subsubsection{Oxidative Protein Folding System}

Disulfide bond protein A (DsbA) and DsbB are periplasmic oxidoreductases required for disulfide bond formation in protein substrates. DsbA is a periplasmic protein that belongs to the thioredoxin superfamily, with an active site CXXC motif embedded in a thioredoxin-like fold and a highly conserved cis-proline in an adjacent loop. DsbA catalyzes the formation of disulfide bonds between thiol groups of two cysteine residues [263]. DsbA is kept in an oxidized state by DsbB reductase, which transfers electrons to quinone through the electron transfer system [269]. DsbB is an inner membrane protein and a member of the vitamin K epoxide reductase superfamily [152]. N. gonorrhoeae encodes two DsbA oxidoreductases. DsbA1 is a lipoprotein bound to the inner membrane, while DsbA3 is a soluble periplasmic protein [154].

Inactivation of the DsbA/DsbB oxidative system has pleiotropic effects on various virulence-associated phenotypes and decreases survival in in vivo infection models of many Gram-negative pathogens [166]. Inactivation of $d s b A 1 / d s b A 2$ in N. meningitidis causes the inefficient folding of PilE and PilQ, resulting in reduced colonization and competence [154,156], while inactivation of $d s b A 3$ results in instability and loss of function in EptA [270]. At this stage, no studies have characterized the effects of $d s b B$ loss in Neisseria species.

Previous studies have identified small-molecule inhibitors, phenylthiazole, benzofuran, and pyridazinone derivatives, against the DsbA/DsbB system in E. coli. Pyridazinonebased compounds $[161,163,165,169]$ bound to $E c D s b B$ at the quinone-binding site between the first two transmembrane segments, competing with quinone, or to a segment of the second periplasmic loop that interacts with EcDsbA [164,271]. Phenylthiazole and benzofuranbased compounds bound to the hydrophobic groove of $E c \mathrm{DsbA}$, which is required for interaction with $E c D s b B[163,169]$. Phenylalanine and tyrosine-based phenylthiazole derivatives were also found to selectively inhibit $E c D s b A$ in in vitro assays, with reduced motility in soft agar and no effect on growth in liquid media [163]. However, these compounds have not been trialed in N. gonorrhoeae.

\subsection{Adhesion and Invasion}

As described earlier, pathogenic Neisseria species express numerous features that facilitate the attachment and invasion of host cells to begin the cycle of infection. The first step of infection relies heavily on attachment and colonization through microcolony formation on the epithelial cell surface [70,272]. This process is mediated by tfp, an OM structure that is also responsible for enabling transformation competence, immune evasion through antigenic and phase variation, twitching motility, and protection from CAMP-, ROS- and PMN-killing mechanisms [273-281]. Additionally, gonococci express Opa proteins that are important for facilitating attachment to host cells via glycan binding $[65,66,187,282]$. Therefore, tfp and Opa proteins represent attractive targets that prevent gonococcal-host interactions.

\subsubsection{Type IV Pili}

Tfp are long filamentous structures extending from the inner membrane to the bacterial surface, passing through the outer membrane via PilQ $[283,284]$. It is composed of the major pilin, PilE, and other minor pilins such as ComP, PilV, PilC and PilH- 
L $[173,177,272,281,285,286]$. The tfp is a highly dynamic structure which undergoes rapid cycles of extension and retraction mediated by PilF and PilT, respectively $[175,176,287]$.

Two recent studies have identified inhibitors of neisserial tfp. The first inhibitor, referred to as compound B in the publication, was identified through a phenotypic screen and successfully prevented the adherence and formation of $N$. meningitidis microcolonies on the human umbilical vein endothelial cell surface [181]. Cellular and in vitro experiments showed that compound B could inhibit the PilF ATPase enzymatic activity resulting in lowered surface expression levels of tfp. Since compound B did not show any inhibitory activity on PilT, this strongly indicates an inhibitory effect on tfp assembly. Additionally, compound B could also prevent the autoaggregation of $N$. gonorrhoeae and induced the disaggregation of preformed gonococcal aggregates, indicating a potential broad-spectrum application. In the same study, structure-activity relationship analysis of compound B showed that the 2,4-dimethoxybenzoyl and piperidine moieties can be modified without affecting efficiency. As such, these components could be modified in future studies to obtain more soluble and stable inhibitors.

The second inhibitor trifluoperazine and related phenothiazines are part of a group of anti-psychotic drugs. Unlike compound B, the inhibitors identified by Denis et al. (2019) [182] do not directly target tfp. Instead, the phenothiazine derivatives affect the function of the $\mathrm{Na}^{+}$-pumping NADH:quinone oxidoreductase $\left(\mathrm{Na}^{+}-\mathrm{NQR}\right)$ in $\mathrm{N}$. meningitidis and $N$. gonorrhoeae, which result in a reduction in tfp twitching motility and the dispersal of bacterial aggregates [182]. Mice infected with N. meningitidis treated with the both phenothiazine and antibiotics had reduced bacteremia and increased survival, highlighting the importance of preventing tfp-mediated pathogenesis.

The effects of both compounds on piliation were fast acting, reflecting the rapid dynamics of the tfp [181,182]. Additionally, both studies showed that although these compounds were initially designed to inhibit $N$. meningitidis, they are also effective on other Gram-negative tfp-expressing bacterial pathogens such as $N$. gonorrhoeae and $P$. aeruginosa. Further investigations into targeting tfp should be performed due to the broad range of pathogens that rely on piliation as a virulence factor.

A separate approach to blocking tfp-mediated attachment to host cells has been recently described by Poole et al. (2020) [183] who screened a library of FDA-approved drugs for binding to the I-domain of complement receptor 3 (CR3). They retrieved two drugs, methyldopa and carbamazepine, which bound with high affinity to the CR3 receptor. Using a docking model, they also synthesized a peptide, G2, which bound with such high affinity to the I-domain of CR3 that it inhibits tfp-mediated gonococcal colonization of primary cervical cells.

\subsubsection{Mannose-Binding (Opa) Proteins}

Opa proteins are OM proteins that promote intimate adhesion to CEACAM and glycans on host epithelial cells, and are observed to be expressed by gonococci isolated from human male models of infection [184,185,188]. Cole et al. (2010) [288] showed that Opa proteins promote persistent late stage of infection in the female murine genital tract. This study and another by Koch (1947) [289] suggested that expression of Opa variants may have a link to stages of the menstrual cycle.

A study by Semchenko et al. (2019) [190] used a glycan array analysis to investigate the glycan binding profile of $N$. gonorrhoeae and the proteins that mediate this interaction. The highest percentage of bound glycans were glycosaminoglycans, such as HSPG, and mannosylated glycans. Using surface plasmon resonance experiments, the glycan that had the highest-affinity interaction was $\alpha 1-2$-mannobiose and liquid chromatographymass spectrometry was used to successfully identify three Opa proteins that were the most abundant mannose-binding proteins. A second surface plasmon resonance assay confirmed that Opa-expressing gonococci had a 6- to 27-fold higher affinity to mannosyl glycans than Opa-nonexpressing gonococci. Since mannose was found on genital tract epithelial cells, Semchenko and collaborators performed infection inhibition assays using the mannose- 
binding lectin ConA or $\alpha$-methyl D-mannoside (mannose-binding protein antagonist) pretreated epithelial cells. Using either inhibitor resulted in a clear reduction in gonococcal adherence to primary cervical epithelial cells and urethral epithelial cells. These results affirmed the need for the development of inhibitors specific to Opa/mannose-binding proteins as gonococcal anti-infectives.

\section{Considerations for Further Clinical Development of AVTs}

Although there is a considerable number of AVTs for many bacterial pathogens in pre-clinical development $[106,290]$, licensing pathways for these compounds remain largely underdeveloped. Provisionally, if the compounds are novel, they are likely to progress via the same regulatory pathway as antibiotics, which may take as long as 10-15 years (Table 2) [291]. However, a shortened licensing pipeline of 3-12 years is possible if the AVT is discovered in previously FDA-approved compound library and shows efficacy in phase 2 trials [292].

One outstanding advantage for the development of AVTs against $N$. gonorrhoeae is that this field has access to male human models of infection in the pre-clinical development phase $[179,293]$. Human models of infection can be used to validate the chosen target for AVT development and establish the end points (e.g., no colonization by the pathogen or reduction in symptoms), which can be then used to develop dosing strategies for phase 1 trials. Three AVT targets-EptA, tfp and Opa mutants-have been tested in human models to validate them for therapeutic intervention (Table 1). Phase 0 trials of fewer than 15 people could be used to examine the efficacy of AVTs and could be used as go-no-go breakpoints for candidates that will progress to the more expensive and lengthy phase 1 and 2 trials [292]. This should reduce the failure rates in the development of AVTs and shorten their time to licensing (Table 2).

Table 2. Characteristics of AVTs, antibiotics and vaccines *.

\begin{tabular}{|c|c|c|c|}
\hline Characteristics & AVTs & Antibiotics & $\begin{array}{l}\text { Hypothetical } \\
\text { Vaccine }\end{array}$ \\
\hline Mode of action & $\begin{array}{c}\text { Selective inhibition of } \\
\text { pathogens, preserves } \\
\text { the microbiome }\end{array}$ & $\begin{array}{l}\text { Broad spectrum killing of } \\
\text { microorganisms, removes } \\
\text { the microbiome }\end{array}$ & $\begin{array}{c}\text { Selective inhibition of } \\
\text { pathogen, preserves } \\
\text { the microbiome }\end{array}$ \\
\hline $\begin{array}{l}\text { Mechanism of } \\
\text { action }\end{array}$ & $\begin{array}{l}\text { Tailored to prevent } \\
\text { colonization, } \\
\text { transmission, and } \\
\text { infection by a } \\
\text { pathogen }\end{array}$ & $\begin{array}{c}\text { Kills systemic } \\
\text { microorganisms- } \\
\text { resolves acute infections. } \\
\text { Not used for } \\
\text { asymptomatic infections }\end{array}$ & $\begin{array}{l}\text { Prevents acute } \\
\text { infection by a } \\
\text { pathogen. In some } \\
\text { instances, vaccines } \\
\text { can prevent } \\
\text { colonization and } \\
\text { transmission of the } \\
\text { pathogen. }\end{array}$ \\
\hline Use & $\begin{array}{l}\text { Pre-exposure } \\
\text { prophylaxis or } \\
\text { therapeutic }\end{array}$ & Therapeutic & $\begin{array}{l}\text { Pre-exposure } \\
\text { therapeutic }\end{array}$ \\
\hline Dose & $\begin{array}{l}\text { Multiple dosing as } \\
\text { needed }\end{array}$ & Multiple dosing, $3-4$ days & $1-3$ doses \\
\hline $\begin{array}{c}\text { Route of } \\
\text { administration }\end{array}$ & Oral, topical & Oral, injectable & Injectable \\
\hline
\end{tabular}


Table 2. Cont.

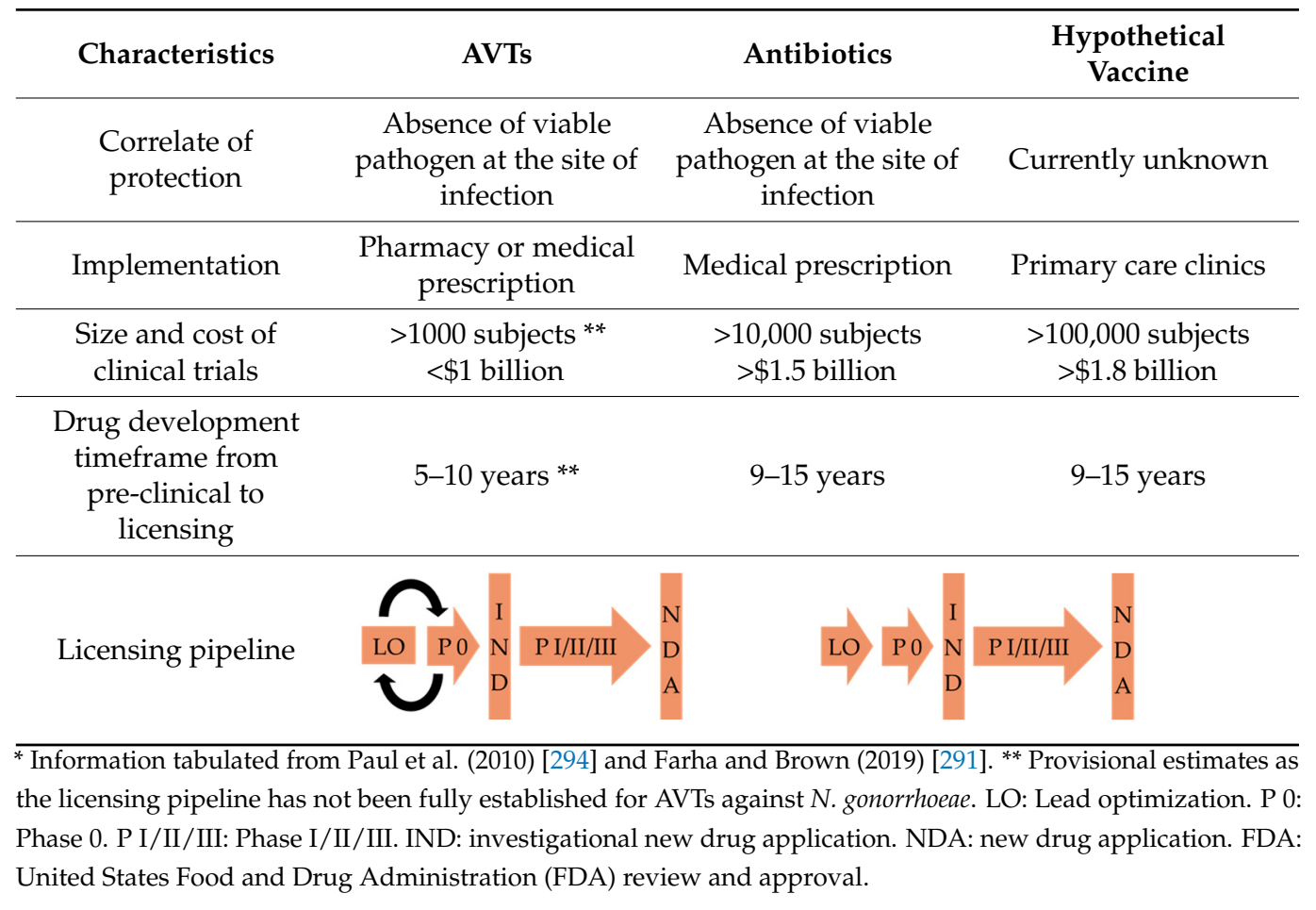

Dependent upon the mode of action of an AVT, some may have properties more similar to antibiotics while others act as adjuvants to antibiotic therapy [295]. Vaccines are targeted against pathogens with generally no or very little cross-over against other microbial species and are administered pre-emptively against infection, while antibiotics are administered to cure acute symptomatic infections. In the case of N. gonorrhoeae, symptomatic infections in men and PID in women are treated with antibiotics at a late stage of the infection where inflammation may cause long-term side effects such as infertility [296] and adverse outcomes for pregnancy [297]. Thus, although antibiotic treatment suppresses further transmission in the community, most successfully via males, intervention is too late to either completely resolve transmission in the community or prevent long-term morbidity from asymptomatic infections in women. AVTs that could be applied preemptively in the community to suppress asymptomatic transmission are likely to have the highest benefit, particularly for women who are at the highest risk of developing PID which increases the risk of infertility. Modes of delivery that would most likely benefit women would either involve oral delivery or direct topical applications via hygiene products such as commercial vaginal microbicides, some of which have viricidal and anti-chlamydial properties [298-301].

\section{Conclusions}

Given the challenges in the development of antibiotics and vaccines against gonorrhea, AVTs are a viable alternative, especially where candidate targets have been validated in human models of infection and correlates for protection have been established. AVTs may find roles as antibiotic adjuvants [295] for traditional antibiotic therapy to reverse development of antibiotic resistance or may find a wider role as an intervention that can reduce asymptomatic infections which drive outbreaks and increase the risk of long-term morbidity in women.

Author Contributions: All authors contributed to the writing of the manuscript. K.Y.L.L. and C.M.K. edited the manuscript. E.C.H. designed the figures. K.A.S., M.S.-T. and C.M.K. reviewed and approved the manuscript. All authors have read and agreed to the published version of the manuscript. 
Funding: K.Y.L.L. was supported by a Scholarship for International Research Fees (SIRF) from the University of Western Australia, C.A.M. was supported by a PhD scholarship from the Amanda Young Foundation, E.C.H. and E.C.M. are supported by Research Training Program (RTP) PhD scholarships from the University of Western Australia, V.C.T. is supported by University International Fee Scholarship (UIFS) and University Postgraduate Award (International Students) (UPAIS) from the University of Western Australia, E.A.K. and N.R.M. are supported by Research Training Program (RTP) PhD scholarships from Murdoch University, and E.A.K. also received a top-up scholarship from Defence Material Technology Centre (DMTC).

Institutional Review Board Statement: Not applicable.

Informed Consent Statement: Not applicable.

Data Availability Statement: Not applicable.

Conflicts of Interest: The authors declare no conflict of interest.

\section{References}

1. Rowley, J.; Vander Hoorn, S.; Korenromp, E.; Low, N.; Unemo, M.; Abu-Raddad, L.J.; Chico, R.M.; Smolak, A.; Newman, L.; Gottlieb, S.; et al. Chlamydia, gonorrhoea, trichomoniasis and syphilis: Global prevalence and incidence estimates, 2016. Bull. World Health Organ. 2019, 97, 548-562. [CrossRef] [PubMed]

2. Centers for Disease Control and Prevention. Sexually Transmitted Disease Surveillance 2018; Department of Health and Human Services: Atlanta, GA, USA, 2019. [CrossRef]

3. Owusu-Edusei, K.J.; Chesson, H.W.; Gift, T.L.; Tao, G.; Mahajan, R.; Ocfemia, M.C.B.; Kent, C.K. The estimated direct medical cost of selected sexually transmitted infections in the United States, 2008. Sex. Transm. Dis. 2013, 40, 197-201. [CrossRef] [PubMed]

4. Sherrard, J.; Barlow, D. Gonorrhoea in men: Clinical and diagnostic aspects. Genitourin. Med. 1996, 72, 422-426. [CrossRef] [PubMed]

5. Kent, C.K.; Chaw, J.K.; Wong, W.; Liska, S.; Gibson, S.; Hubbard, G.; Klausner, J.D. Prevalence of rectal, urethral, and pharyngeal chlamydia and gonorrhea detected in 2 clinical settings among men who have sex with men: San Francisco, California, 2003. Clin. Infect. Dis. 2005, 41, 67-74. [CrossRef]

6. Morris, S.R.; Klausner, J.D.; Buchbinder, S.P.; Wheeler, S.L.; Koblin, B.; Coates, T.; Chesney, M.; Colfax, G.N. Prevalence and incidence of pharyngeal gonorrhea in a longitudinal sample of men who have sex with men: The EXPLORE study. Clin. Infect. Dis. 2006, 43, 1284-1289. [CrossRef]

7. Kinghorn, G. Pharyngeal gonorrhoea: A silent cause for concern. Sex. Transm. Infect. 2010, 86, 413-414. [CrossRef]

8. Peters, R.P.; Verweij, S.P.; Nijsten, N.; Ouburg, S.; Mutsaers, J.; Jansen, C.L.; van Leeuwen, A.P.; Morré, S.A. Evaluation of sexual history-based screening of anatomic sites for Chlamydia trachomatis and Neisseria gonorrhoeae infection in men having sex with men in routine practice. BMC Infect. Dis. 2011, 11, 203. [CrossRef]

9. McCormack, W.M.; Johnson, K.; Stumacher, R.J.; Donner, A.; Rychwalski, R. Clinical spectrum of gonococcal infection in women. Lancet 1977, 309, 1182-1185. [CrossRef]

10. Walker, C.K.; Sweet, R.L. Gonorrhea infection in women: Prevalence, effects, screening, and management. Int. J. Womens Health 2011, 3, 197-206. [CrossRef]

11. Ding, J.; Rapista, A.; Teleshova, N.; Mosoyan, G.; Jarvis, G.A.; Klotman, M.E.; Chang, T.L. Neisseria gonorrhoeae enhances HIV-1 infection of primary resting CD4+ T cells through TLR2 activation. J. Immunol. 2010, 184, 2814-2824. [CrossRef]

12. Jarvis, G.A.; Chang, T.L. Modulation of HIV transmission by Neisseria gonorrhoeae: Molecular and immunological aspects. Curr. HIV Res. 2012, 10, 211-217. [CrossRef] [PubMed]

13. Malott, R.J.; Keller, B.O.; Gaudet, R.G.; McCaw, S.E.; Lai, C.C.; Dobson-Belaire, W.N.; Hobbs, J.L.; Michael, F.S.; Cox, A.D.; Moraes, T.F. Neisseria gonorrhoeae-derived heptose elicits an innate immune response and drives HIV-1 expression. Proc. Natl. Acad. Sci. USA 2013, 110, 10234-10239. [CrossRef] [PubMed]

14. Sanyal, A.; Shen, C.; Ding, M.; Reinhart, T.A.; Chen, Y.; Sankapal, S.; Gupta, P. Neisseria gonorrhoeae uses cellular proteins CXCL10 and IL8 to enhance HIV-1 transmission across cervical mucosa. Am. J. Reprod. Immunol. 2019, 81, e13111. [CrossRef] [PubMed]

15. Guvenc, F.; Kaul, R.; Gray-Owen, S.D. Intimate relations: Molecular and immunologic interactions between Neisseria gonorrhoeae and HIV-1. Front. Microbiol. 2020, 11, 1299. [CrossRef] [PubMed]

16. Maxwell, G.L.; Watson, W.J. Preterm premature rupture of membranes: Results of expectant management in patients with cervical cultures positive for group B streptococcus or Neisseria gonorrhoeae. Am. J. Obstet. Gynecol. 1992, 166, 945-949. [CrossRef]

17. Heumann, C.L.; Quilter, L.A.S.; Eastment, M.C.; Heffron, R.; Hawes, S.E. Adverse birth outcomes and maternal Neisseria gonorrhoeae infection: A population-based cohort study in Washington State. Sex. Transm. Dis. 2017, 44, 266-271. [CrossRef]

18. Thompson, T.R.; Swanson, R.E.; Wiesner, P.J. Gonococcal ophthalmia neonatorum: Relationship of time of infection to relevant control measures. JAMA 1974, 228, 186-188. [CrossRef]

19. Rees, E.; Tait, I.A.; Hobson, D.; Byng, R.E.; Johnson, F.W. Neonatal conjunctivitis caused by Neisseria gonorrhoeae and Chlamydia trachomatis. Sex. Transm. Infect. 1977, 53, 173-179. [CrossRef] 
20. Laga, M.; Meheus, A.; Piot, P. Epidemiology and control of gonococcal ophthalmia neonatorum. Bull. World Health Organ. 1989, $67,471-477$.

21. Epling, J. Bacterial conjunctivitis. BMJ Clin. Evid. 2012, 2012, 0704.

22. Fung, M.; Scott, K.C.; Kent, C.K.; Klausner, J.D. Chlamydial and gonococcal reinfection among men: A systematic review of data to evaluate the need for retesting. Sex. Transm. Infect. 2007, 83, 304-309. [CrossRef] [PubMed]

23. Jerse, A.E.; Bash, M.C.; Russell, M.W. Vaccines against gonorrhea: Current status and future challenges. Vaccine 2014, 32, 1579-1587. [CrossRef] [PubMed]

24. Petousis-Harris, H.; Paynter, J.; Morgan, J.; Saxton, P.; McArdle, B.; Goodyear-Smith, F.; Black, S. Effectiveness of a group B outer membrane vesicle meningococcal vaccine against gonorrhoea in New Zealand: A retrospective case-control study. Lancet 2017, 390, 1603-1610. [CrossRef]

25. Semchenko, E.A.; Tan, A.; Borrow, R.; Seib, K.L. The serogroup B meningococcal vaccine Bexsero elicits antibodies to Neisseria gonorrhoeae. Clin. Infect. Dis. 2019, 69, 1101-1111. [CrossRef]

26. Gottlieb, S.L.; Jerse, A.E.; Delany-Moretlwe, S.; Deal, C.; Giersing, B.K. Advancing vaccine development for gonorrhoea and the Global STI Vaccine Roadmap. Sex. Health 2019, 16, 426-432. [CrossRef]

27. World Health Organization. WHO Guidelines for the Treatment of Neisseria gonorrhoeae; World Health Organization: Geneva, Switzerland, 2016; Available online: http:/ / www.who.int/reproductivehealth/publications/rtis/gonorrhoea-treatment-guidelines/en/ (accessed on 18 September 2020).

28. Workowski, K.A.; Bolan, G.A. Sexually transmitted diseases treatment guidelines, 2015. MMWR Recomm. Rep. Morb. Mortal. Wkly. Rep. Recomm. Rep. 2015, 64, 1-137.

29. Ison, C.A. Biology of Neisseria gonorrhoeae and the clinical picture of infection. In Sexually Transmitted Infections and Sexually Transmitted Diseases; Gross, G.E., Tyring, S.K., Eds.; Springer: Berlin/Heidelberg, Germany, 2011; pp. 77-90. ISBN 978-3-642-146633.

30. Centers for Disease Control and Prevention. Cephalosporin susceptibility among Neisseria gonorrhoeae isolates-United States, 2000-2010. MMWR Morb. Mortal. Wkly. Rep. 2011, 60, 873-877.

31. Unemo, M.; Nicholas, R.A. Emergence of multidrug-resistant, extensively drug-resistant and untreatable gonorrhea. Future Microbiol. 2012, 7, 1401-1422. [CrossRef]

32. Centers for Disease Control and Prevention. CDC grand rounds: The growing threat of multidrug-resistant gonorrhea. $M M W R$ Morb. Mortal. Wkly. Rep. 2013, 62, 103-106.

33. Unemo, M.; Golparian, D.; Hellmark, B. First three Neisseria gonorrhoeae isolates with high-level resistance to azithromycin in Sweden: A threat to currently available dual-antimicrobial regimens for treatment of gonorrhea? Antimicrob. Agents Chemother. 2014, 58, 624-625. [CrossRef]

34. Fifer, H.; Natarajan, U.; Jones, L.; Alexander, S.; Hughes, G.; Golparian, D.; Unemo, M. Failure of dual antimicrobial therapy in treatment of gonorrhea. N. Engl. J. Med. 2016, 374, 2504-2506. [CrossRef] [PubMed]

35. Wi, T.; Lahra, M.M.; Ndowa, F.; Bala, M.; Dillon, J.-A.R.; Ramon-Pardo, P.; Eremin, S.R.; Bolan, G.; Unemo, M. Antimicrobial resistance in Neisseria gonorrhoeae: Global surveillance and a call for international collaborative action. PLoS Med. 2017, 14, e1002344. [CrossRef] [PubMed]

36. Katz, A.R.; Komeya, A.Y.; Kirkcaldy, R.D.; Whelen, A.C.; Soge, O.O.; Papp, J.R.; Kersh, E.N.; Wasserman, G.M.; O'Connor, N.P.; O'Brien, P.S.; et al. Cluster of Neisseria gonorrhoeae isolates with high-level azithromycin resistance and decreased ceftriaxone susceptibility, Hawaii, 2016. Clin. Infect. Dis. 2017, 65, 918-923. [CrossRef] [PubMed]

37. Lahra, M.M.; Martin, I.; Demczuk, W.; Jennison, A.V.; Lee, K.-I.; Nakayama, S.-I.; Lefebvre, B.; Longtin, J.; Ward, A.; Mulvey, M.R.; et al. Cooperative recognition of internationally disseminated ceftriaxone-resistant Neisseria gonorrhoeae strain. Emerg. Infect. Dis. 2018, 24, 735-740. [CrossRef]

38. Eyre, D.W.; Sanderson, N.D.; Lord, E.; Regisford-Reimmer, N.; Chau, K.; Barker, L.; Morgan, M.; Newnham, R.; Golparian, D.; Unemo, M.; et al. Gonorrhoea treatment failure caused by a Neisseria gonorrhoeae strain with combined ceftriaxone and high-level azithromycin resistance, England, February 2018. Eurosurveillance 2018, 23, 1800323. [CrossRef]

39. Centers for Disease Control and Prevention. Antibiotic Resistance Threats in the United States, 2019; Department of Health and Human Services: Atlanta, GA, USA, 2019. [CrossRef]

40. Ko, K.K.K.; Chio, M.T.W.; Goh, S.S.; Tan, A.L.; Koh, T.H.; Rahman, N.B.A. First case of ceftriaxone-resistant multidrug-resistant Neisseria gonorrhoeae in Singapore. Antimicrob. Agents Chemother. 2019, 63, e02624-18. [CrossRef]

41. Cosgrove, S.E. The relationship between antimicrobial resistance and patient outcomes: Mortality, length of hospital stay, and health care costs. Clin. Infect. Dis. 2006, 42, S82-S89. [CrossRef]

42. Roberts, R.R.; Hota, B.; Ahmad, I.; Scott, R.D.; Foster, S.D.; Abbasi, F.; Schabowski, S.; Kampe, L.M.; Ciavarella, G.G.; Supino, M.; et al. Hospital and societal costs of antimicrobial-resistant infections in a Chicago teaching hospital: Implications for antibiotic stewardship. Clin. Infect. Dis. 2009, 49, 1175-1184. [CrossRef]

43. Mainous, A.G.; Diaz, V.A.; Matheson, E.M.; Gregorie, S.H.; Hueston, W.J. Trends in hospitalizations with antibiotic-resistant infections: U.S., 1997-2006. Public Health Rep. 2011, 126, 354-360. [CrossRef]

44. Friedman, N.D.; Temkin, E.; Carmeli, Y. The negative impact of antibiotic resistance. Clin. Microbiol. Infect. 2016, 22, 416-422. [CrossRef] 
45. Opatowski, M.; Tuppin, P.; Cosker, K.; Touat, M.; Lagasnerie, G.D.; Guillemot, D.; Salomon, J.; Brun-Buisson, C.; Watier, L. Hospitalisations with infections related to antimicrobial-resistant bacteria from the French nationwide hospital discharge database, 2016. Epidemiol. Infect. 2019, 147, e144. [CrossRef]

46. Golparian, D.; Shafer, W.M.; Ohnishi, M.; Unemo, M. Importance of multidrug efflux pumps in the antimicrobial resistance property of clinical multidrug-resistant isolates of Neisseria gonorrhoeae. Antimicrob. Agents Chemother. 2014, 58, 3556-3559. [CrossRef] [PubMed]

47. Taylor, S.N.; Morris, D.H.; Avery, A.K.; Workowski, K.A.; Batteiger, B.E.; Tiffany, C.A.; Perry, C.R.; Raychaudhuri, A.; ScangarellaOman, N.E.; Hossain, M.; et al. Gepotidacin for the treatment of uncomplicated urogenital gonorrhea: A phase 2, randomized, dose-ranging, single-oral dose evaluation. Clin. Infect. Dis. Off. Publ. Infect. Dis. Soc. Am. 2018, 67, 504-512. [CrossRef] [PubMed]

48. Taylor, S.N.; Marrazzo, J.; Batteiger, B.E.; Hook, E.W.; Seña, A.C.; Long, J.; Wierzbicki, M.R.; Kwak, H.; Johnson, S.M.; Lawrence, K.; et al. Single-dose zoliflodacin (ETX0914) for treatment of urogenital gonorrhea. N. Engl. J. Med. 2018, 379, 1835-1845. [CrossRef] [PubMed]

49. Chen, M.Y.; McNulty, A.; Avery, A.; Whiley, D.; Tabrizi, S.N.; Hardy, D.; Das, A.F.; Nenninger, A.; Fairley, C.K.; Hocking, J.S.; et al. Solithromycin versus ceftriaxone plus azithromycin for the treatment of uncomplicated genital gonorrhoea (SOLITAIRE-U): A randomised phase 3 non-inferiority trial. Lancet Infect. Dis. 2019, 19, 833-842. [CrossRef]

50. Jacobsson, S.; Mason, C.; Khan, N.; Meo, P.; Unemo, M. In vitro activity of the novel oral antimicrobial SMT-571, with a new mechanism of action, against MDR and XDR Neisseria gonorrhoeae: Future treatment option for gonorrhoea? J. Antimicrob. Chemother. 2019, 74, 1591-1594. [CrossRef] [PubMed]

51. Moran, J.S. Treating uncomplicated Neisseria gonorrhoeae infections: Is the anatomic site of infection important? Sex. Transm. Dis. 1995, 22, 39-47. [CrossRef] [PubMed]

52. Manavi, K.; Young, H.; McMillan, A. The outcome of oropharyngeal gonorrhoea treatment with different regimens. Int. J. STD AIDS 2005, 16, 68-70. [CrossRef]

53. Chow, E.P.F.; Walker, S.; Hocking, J.S.; Bradshaw, C.S.; Chen, M.Y.; Tabrizi, S.N.; Howden, B.P.; Law, M.G.; Maddaford, K.; Read, T.R.H.; et al. A multicentre double-blind randomised controlled trial evaluating the efficacy of daily use of antibacterial mouthwash against oropharyngeal gonorrhoea among men who have sex with men: The OMEGA (Oral Mouthwash use to Eradicate GonorrhoeA) study protocol. BMC Infect. Dis. 2017, 17, 456. [CrossRef]

54. Chow, E.P.F.; Williamson, D.A.; Hocking, J.S.; Law, M.G.; Maddaford, K.; Bradshaw, C.S.; McNulty, A.; Templeton, D.J.; Moore, R.; Murray, G.L.; et al. Antiseptic mouthwash for gonorrhoea prevention (OMEGA): A randomised, double-blind, parallel-group, multicentre trial. Sex. Health 2020, 17, viii. [CrossRef]

55. Chow, E.P.F.; Maddaford, K.; Hocking, J.S.; Bradshaw, C.S.; Wigan, R.; Chen, M.Y.; Howden, B.P.; Williamson, D.A.; Fairley, C.K. An open-label, parallel-group, randomised controlled trial of antiseptic mouthwash versus antibiotics for oropharyngeal gonorrhoea treatment (OMEGA2). Sci. Rep. 2020, 10, 19386. [CrossRef] [PubMed]

56. Hung, M.-C.; Christodoulides, M. The biology of Neisseria adhesins. Biology 2013, 2, 1054-1109. [CrossRef] [PubMed]

57. Seifert, H.S. Questions about gonococcal pilus phase- and antigenic variation. Mol. Microbiol. 1996, 21, 433-440. [CrossRef] [PubMed]

58. Hill, S.A.; Masters, T.L.; Wachter, J. Gonorrhea-An evolving disease of the new millennium. Microb. Cell 2016, 3, 371. [CrossRef] [PubMed]

59. Kirchner, M.; Heuer, D.; Meyer, T.F. CD46-independent binding of neisserial type IV pili and the major pilus adhesin, PilC, to human epithelial cells. Infect. Immun. 2005, 73, 3072. [CrossRef]

60. Jonsson, A.-B.; Ilver, D.; Falk, P.; Pepose, J.; Normark, S. Sequence changes in the pilus subunit lead to tropism variation of Neisseria gonorrhoeae to human tissue. Mol. Microbiol. 1994, 13, 403-416. [CrossRef]

61. Long, C.D.; Madraswala, R.N.; Seifert, H.S. Comparisons between colony phase variation of Neisseria gonorrhoeae FA1090 and pilus, pilin, and S-pilin expression. Infect. Immun. 1998, 66, 1918-1927. [CrossRef]

62. Stern, A.; Brown, M.; Nickel, P.; Meyer, T.F. Opacity genes in Neisseria gonorrhoeae: Control of phase and antigenic variation. Cell 1986, 47, 61-71. [CrossRef]

63. Edwards, J.L.; Apicella, M.A. The molecular mechanisms used by Neisseria gonorrhoeae to initiate infection differ between men and women. Clin. Microbiol. Rev. 2004, 17, 965-981. [CrossRef]

64. Quillin, S.J.; Seifert, H.S. Neisseria gonorrhoeae host adaptation and pathogenesis. Nat. Rev. Microbiol. 2018, 16, 226-240. [CrossRef]

65. Van Putten, J.P.; Paul, S.M. Binding of syndecan-like cell surface proteoglycan receptors is required for Neisseria gonorrhoeae entry into human mucosal cells. EMBO J. 1995, 14, 2144-2154. [CrossRef] [PubMed]

66. Chen, T.; Belland, R.J.; Wilson, J.; Swanson, J. Adherence of pilus-Opa+ gonococci to epithelial cells in vitro involves heparan sulfate. J. Exp. Med. 1995, 182, 511-517. [CrossRef] [PubMed]

67. Porat, N.; Apicella, M.A.; Blake, M.S. Neisseria gonorrhoeae utilizes and enhances the biosynthesis of the asialoglycoprotein receptor expressed on the surface of the hepatic HepG2 cell line. Infect. Immun. 1995, 63, 1498-1506. [CrossRef] [PubMed]

68. Harvey, H.A.; Porat, N.; Campbell, C.A.; Jennings, M.; Gibson, B.W.; Phillips, N.J.; Apicella, M.A.; Blake, M.S. Gonococcal lipooligosaccharide is a ligand for the asialoglycoprotein receptor on human sperm. Mol. Microbiol. 2000, 36, 1059-1070. [CrossRef] [PubMed] 
69. Harvey, H.A.; Jennings, M.P.; Campbell, C.A.; Williams, R.; Apicella, M.A. Receptor-mediated endocytosis of Neisseria gonorrhoeae into primary human urethral epithelial cells: The role of the asialoglycoprotein receptor. Mol. Microbiol. 2001, 42, 659-672. [CrossRef]

70. Higashi, D.L.; Lee, S.W.; Snyder, A.; Weyand, N.J.; Bakke, A.; So, M. Dynamics of Neisseria gonorrhoeae attachment: Microcolony development, cortical plaque formation, and cytoprotection. Infect. Immun. 2007, 75, 4743-4753. [CrossRef]

71. Anderson, M.T.; Byerly, L.; Apicella, M.A.; Seifert, H.S. Seminal plasma promotes Neisseria gonorrhoeae aggregation and biofilm formation. J. Bacteriol. 2016, 198, 2228-2235. [CrossRef]

72. Merz, A.J.; Rifenbery, D.B.; Arvidson, C.G.; So, M. Traversal of a polarized epithelium by pathogenic Neisseriae: Facilitation by type IV pili and maintenance of epithelial barrier function. Mol. Med. 1996, 2, 745-754. [CrossRef]

73. Wang, J.; Gray-Owen, S.D.; Knorre, A.; Meyer, T.F.; Dehio, C. Opa binding to cellular CD66 receptors mediates the transcellular traversal of Neisseria gonorrhoeae across polarized T84 epithelial cell monolayers. Mol. Microbiol. 1998, 30, 657-671. [CrossRef]

74. Ilver, D.; Källström, H.; Normark, S.; Jonsson, A.-B. Transcellular passage of Neisseria gonorrhoeae involves pilus phase variation. Infect. Immun. 1998, 66, 469-473. [CrossRef]

75. Sinha, R.K.; Rosenthal, R.S. Release of soluble peptidoglycan from growing gonococci: Demonstration of anhydro-muramylcontaining fragments. Infect. Immun. 1980, 29, 914-925. [PubMed]

76. Kaparakis, M.; Turnbull, L.; Carneiro, L.; Firth, S.; Coleman, H.A.; Parkington, H.C.; Bourhis, L.L.; Karrar, A.; Viala, J.; Mak, J.; et al. Bacterial membrane vesicles deliver peptidoglycan to NOD1 in epithelial cells. Cell. Microbiol. 2010, 12, 372-385. [CrossRef] [PubMed]

77. Liu, M.; John, C.M.; Jarvis, G.A. Phosphoryl moieties of lipid A from Neisseria meningitidis and N. gonorrhoeae lipooligosaccharides play an important role in activation of both MyD88- and TRIF-Dependent TLR4-MD-2 signaling pathways. J. Immunol. 2010, 185, 6974-6984. [CrossRef] [PubMed]

78. Mavrogiorgos, N.; Mekasha, S.; Yang, Y.; Kelliher, M.A.; Ingalls, R.R. Activation of NOD receptors by Neisseria gonorrhoeae modulates the innate immune response. Innate Immun. 2014, 20, 377-389. [CrossRef] [PubMed]

79. Schwechheimer, C.; Kuehn, M.J. Outer-membrane vesicles from Gram-negative bacteria: Biogenesis and functions. Nat. Rev. Microbiol. 2015, 13, 605-619. [CrossRef] [PubMed]

80. Gaudet, R.G.; Sintsova, A.; Buckwalter, C.M.; Leung, N.; Cochrane, A.; Li, J.; Cox, A.D.; Moffat, J.; Gray-Owen, S.D. Cytosolic detection of the bacterial metabolite HBP activates TIFA-dependent innate immunity. Science 2015, 348, 1251-1255. [CrossRef]

81. Pachathundikandi, K.; Backert, S. Heptose 1,7-bisphosphate directed TIFA oligomerization: A novel PAMP-recognizing signaling platform in the control of bacterial infections. Gastroenterology 2018, 154, 778-783. [CrossRef]

82. Ramsey, K.H.; Schneider, H.; Cross, A.S.; Boslego, J.W.; Hoover, D.L.; Staley, T.L.; Kuschner, R.A.; Deal, C.D. Inflammatory cytokines produced in response to experimental human gonorrhea. J. Infect. Dis. 1995, 172, 186-191. [CrossRef]

83. Zughaier, S.M.; Kandler, J.L.; Balthazar, J.T.; Shafer, W.M. Phosphoethanolamine modification of Neisseria gonorrhoeae lipid A reduces autophagy flux in macrophages. PLoS ONE 2015, 10, e0144347. [CrossRef]

84. Criss, A.K.; Seifert, H.S. A bacterial siren song: Intimate interactions between Neisseria and neutrophils. Nat. Rev. Microbiol. 2012, 10, 178-190. [CrossRef]

85. Roos, D.; van Bruggen, R.; Meischl, C. Oxidative killing of microbes by neutrophils. Microbes Infect. 2003, 5, 1307-1315. [CrossRef] [PubMed]

86. Levy, O. Antimicrobial proteins and peptides: Anti-infective molecules of mammalian leukocytes. J. Leukoc. Biol. 2004, 76, 909-925. [CrossRef]

87. Tseng, H.-J.; Srikhanta, Y.; McEwan, A.G.; Jennings, M.P. Accumulation of manganese in Neisseria gonorrhoeae correlates with resistance to oxidative killing by superoxide anion and is independent of superoxide dismutase activity. Mol. Microbiol. 2001, 40, 1175-1186. [CrossRef] [PubMed]

88. Claverys, J.-P. A new family of high-affinity ABC manganese and zinc permeases. Res. Microbiol. 2001, 152, 231-243. [CrossRef]

89. Seib, K.L.; Wu, H.-J.; Kidd, S.P.; Apicella, M.A.; Jennings, M.P.; McEwan, A.G. Defenses against oxidative stress in Neisseria gonorrhoeae: A system tailored for a challenging environment. Microbiol. Mol. Biol. Rev. 2006, 70, 344-361. [CrossRef] [PubMed]

90. Seib, K.L.; Tseng, H.-J.; McEwan, A.G.; Apicella, M.A.; Jennings, M.P. Defenses against oxidative stress in Neisseria gonorrhoeae and Neisseria meningitidis: Distinctive systems for different lifestyles. J. Infect. Dis. 2004, 190, 136-147. [CrossRef]

91. Archibald, F.S.; Duong, M.N. Superoxide dismutase and oxygen toxicity defenses in the genus Neisseria. Infect. Immun. 1986, 51, 631-641. [CrossRef] [PubMed]

92. Seib, K.L.; Jennings, M.P.; McEwan, A.G. A Sco homologue plays a role in defence against oxidative stress in pathogenic Neisseria. FEBS Lett. 2003, 546, 411-415. [CrossRef]

93. Stohl, E.A.; Seifert, H.S. Neisseria gonorrhoeae DNA recombination and repair enzymes protect against oxidative damage caused by hydrogen peroxide. J. Bacteriol. 2006, 188, 7645-7651. [CrossRef] [PubMed]

94. Kline, K.A.; Seifert, H.S. Mutation of the PriA gene of Neisseria gonorrhoeae affects DNA transformation and DNA repair. J. Bacteriol. 2005, 187, 5347-5355. [CrossRef]

95. LeCuyer, B.E.; Criss, A.K.; Seifert, H.S. Genetic characterization of the nucleotide excision repair system of Neisseria gonorrhoeae. J. Bacteriol. 2010, 192, 665-673. [CrossRef] [PubMed]

96. Johnson, M.B.; Criss, A.K. Resistance of Neisseria gonorrhoeae to neutrophils. Front. Microbiol. 2011, 2, 77. [CrossRef] [PubMed] 
97. Zughaier, S.M.; Kandler, J.L.; Shafer, W.M. Neisseria gonorrhoeae modulates iron-limiting innate immune defenses in macrophages. PLoS ONE 2014, 9, e87688. [CrossRef] [PubMed]

98. Ortiz, M.C.; Lefimil, C.; Rodas, P.I.; Vernal, R.; Lopez, M.; Acuña-Castillo, C.; Imarai, M.; Escobar, A. Neisseria gonorrhoeae modulates immunity by polarizing human macrophages to a M2 profile. PLoS ONE 2015, 10, e0130713. [CrossRef] [PubMed]

99. Jerse, A.E.; Sharma, N.D.; Simms, A.N.; Crow, E.T.; Snyder, L.A.; Shafer, W.M. A gonococcal efflux pump system enhances bacterial survival in a female mouse model of genital tract infection. Infect. Immun. 2003, 71, 5576-5582. [CrossRef] [PubMed]

100. Handing, J.W.; Ragland, S.A.; Bharathan, U.V.; Criss, A.K. The MtrCDE efflux pump contributes to survival of Neisseria gonorrhoeae from human neutrophils and their antimicrobial components. Front. Microbiol. 2018, 9, 2688. [CrossRef] [PubMed]

101. Kraemer, S.A.; Ramachandran, A.; Perron, G.G. Antibiotic pollution in the environment: From microbial ecology to public policy. Microorganisms 2019, 7, 180. [CrossRef]

102. Zhu, Y.-G.; Zhao, Y.; Zhu, D.; Gillings, M.; Penuelas, J.; Ok, Y.S.; Capon, A.; Banwart, S. Soil biota, antimicrobial resistance and planetary health. Environ. Int. 2019, 131, 105059. [CrossRef]

103. Hamilton, H.L.; Dillard, J.P. Natural transformation of Neisseria gonorrhoeae: From DNA donation to homologous recombination. Mol. Microbiol. 2006, 59, 376-385. [CrossRef]

104. Unemo, M.; Shafer, W.M. Antimicrobial resistance in Neisseria gonorrhoeae in the 21st century: Past, evolution, and future. Clin. Microbiol. Rev. 2014, 27, 587-613. [CrossRef]

105. Palace, S.G.; Wang, Y.; Rubin, D.H.; Welsh, M.A.; Mortimer, T.D.; Cole, K.; Eyre, D.W.; Walker, S.; Grad, Y.H. RNA polymerase mutations cause cephalosporin resistance in clinical Neisseria gonorrhoeae isolates. eLife 2020, 9, e51407. [CrossRef] [PubMed]

106. Dickey, S.W.; Cheung, G.Y.C.; Otto, M. Different drugs for bad bugs: Antivirulence strategies in the age of antibiotic resistance. Nat. Rev. Drug Discov. 2017, 16, 457-471. [CrossRef] [PubMed]

107. Foschi, C.; Salvo, M.; Cevenini, R.; Parolin, C.; Vitali, B.; Marangoni, A. Vaginal lactobacilli reduce Neisseria gonorrhoeae viability through multiple strategies: An in vitro study. Front. Cell. Infect. Microbiol. 2017, 7, 502. [CrossRef] [PubMed]

108. Cox, A.D.; Wright, J.C.; Li, J.; Hood, D.W.; Moxon, E.R.; Richards, J.C. Phosphorylation of the lipid A region of meningococcal lipopolysaccharide: Identification of a family of transferases that add phosphoethanolamine to lipopolysaccharide. J. Bacteriol. 2003, 185, 3270-3277. [CrossRef] [PubMed]

109. Lewis, L.A.; Choudhury, B.; Balthazar, J.T.; Martin, L.E.; Ram, S.; Rice, P.A.; Stephens, D.S.; Carlson, R.; Shafer, W.M. Phosphoethanolamine substitution of lipid A and resistance of Neisseria gonorrhoeae to cationic antimicrobial peptides and complementmediated killing by normal human serum. Infect. Immun. 2009, 77, 1112-1120. [CrossRef] [PubMed]

110. Hobbs, M.M.; Anderson, J.E.; Balthazar, J.T.; Kandler, J.L.; Carlson, R.W.; Ganguly, J.; Begum, A.A.; Duncan, J.A.; Lin, J.T.; Sparling, P.F.; et al. Lipid A's structure mediates Neisseria gonorrhoeae fitness during experimental infection of mice and men. $m B i o$ 2013, 4, e00892-13. [CrossRef]

111. Handing, J.W.; Criss, A.K. The lipooligosaccharide-modifying enzyme LptA enhances gonococcal defence against human neutrophils. Cell. Microbiol. 2015, 17, 910-921. [CrossRef]

112. Anandan, A.; Evans, G.L.; Condic-Jurkic, K.; O’Mara, M.L.; John, C.M.; Phillips, N.J.; Jarvis, G.A.; Wills, S.S.; Stubbs, K.A.; Moraes, I.; et al. Structure of a lipid A phosphoethanolamine transferase suggests how conformational changes govern substrate binding. Proc. Natl. Acad. Sci. USA 2017, 114, 2218-2223. [CrossRef]

113. $\mathrm{Wu}, \mathrm{H}$.; Jerse, A.E. $\alpha$-2,3-sialyltransferase enhances Neisseria gonorrhoeae survival during experimental murine genital tract infection. Infect. Immun. 2006, 74, 4094-4103. [CrossRef]

114. Lin, L.Y.-C.; Rakic, B.; Chiu, C.P.C.; Lameignere, E.; Wakarchuk, W.W.; Withers, S.G.; Strynadka, N.C.J. Structure and mechanism of the lipooligosaccharide sialyltransferase from Neisseria meningitidis. J. Biol. Chem. 2011, 286, 37237-37248. [CrossRef]

115. Lewis, L.A.; Gulati, S.; Burrowes, E.; Zheng, B.; Ram, S.; Rice, P.A. $\alpha$-2,3-sialyltransferase expression level impacts the kinetics of lipooligosaccharide sialylation, complement resistance, and the ability of Neisseria gonorrhoeae to colonize the murine genital tract. mBio 2015, 6, e02465-14. [CrossRef]

116. Gulati, S.; Schoenhofen, I.C.; Whitfield, D.M.; Cox, A.D.; Li, J.; Michael, F.S.; Vinogradov, E.V.; Stupak, J.; Zheng, B.; Ohnishi, M.; et al. Utilizing CMP-sialic acid analogs to unravel Neisseria gonorrhoeae lipooligosaccharide-mediated complement resistance and design novel therapeutics. PLoS Pathog. 2015, 11, e1005290. [CrossRef] [PubMed]

117. Shaughnessy, J.; Gulati, S.; Agarwal, S.; Unemo, M.; Ohnishi, M.; Su, X.-H.; Monks, B.G.; Visintin, A.; Madico, G.; Lewis, L.A.; et al. A novel factor $\mathrm{H}-\mathrm{Fc}$ chimeric immunotherapeutic molecule against Neisseria gonorrhoeae. J. Immunol. 2016, 196, 1732-1740. [CrossRef]

118. Gulati, S.; Schoenhofen, I.C.; Lindhout-Djukic, T.; Schur, M.J.; Landig, C.S.; Saha, S.; Deng, L.; Lewis, L.A.; Zheng, B.; Varki, A.; et al. Therapeutic CMP-nonulosonates against multidrug-resistant Neisseria gonorrhoeae. J. Immunol. 2020, 204, $3283-3295$. [CrossRef]

119. Gulati, S.; Schoenhofen, I.C.; Lindhout-Djukic, T.; Lewis, L.A.; Moustafa, I.Y.; Saha, S.; Zheng, B.; Nowak, N.; Rice, P.A.; Varki, A.; et al. Efficacy of antigonococcal CMP-nonulosonate therapeutics require cathelicidins. J. Infect. Dis. 2020, 222, 1641-1650. [CrossRef] [PubMed]

120. Yum, S.; Kim, M.J.; Xu, Y.; Jin, X.L.; Yoo, H.Y.; Park, J.-W.; Gong, J.H.; Choe, K.-M.; Lee, B.L.; Ha, N.-C. Structural basis for the recognition of lysozyme by $\mathrm{MliC}$, a periplasmic lysozyme inhibitor in Gram-negative bacteria. Biochem. Biophys. Res. Commun. 2009, 378, 244-248. [CrossRef] [PubMed] 
121. Ragland, S.A.; Humbert, M.V.; Christodoulides, M.; Criss, A.K. Neisseria gonorrhoeae employs two protein inhibitors to evade killing by human lysozyme. PLoS Pathog. 2018, 14, e1007080. [CrossRef] [PubMed]

122. Zielke, R.A.; Le Van, A.; Baarda, B.I.; Herrera, M.F.; Acosta, C.J.; Jerse, A.E.; Sikora, A.E. SliC is a surface-displayed lipoprotein that is required for the anti-lysozyme strategy during Neisseria gonorrhoeae infection. PLoS Pathog. 2018, 14, e1007081. [CrossRef]

123. Almonacid-Mendoza, H.L.; Humbert, M.V.; Dijokaite, A.; Cleary, D.W.; Soo, Y.; Hung, M.-C.; Orr, C.M.; Machelett, M.M.; Tews, I.; Christodoulides, M. Structure of the recombinant Neisseria gonorrhoeae adhesin complex protein (rNg-ACP) and generation of murine antibodies with bactericidal activity against gonococci. mSphere 2018, 3, e00331-18. [CrossRef]

124. Blundell, J.K.; Smith, G.J.; Perkins, H.R. The peptidoglycan of Neisseria gonorrhoeae: O-acetyl groups and lysozyme sensitivity. FEMS Microbiol. Lett. 1980, 9, 259-261. [CrossRef]

125. Rosenthal, R.S.; Folkening, W.J.; Miller, D.R.; Swim, S.C. Resistance of O-acetylated gonococcal peptidoglycan to human peptidoglycan-degrading enzymes. Infect. Immun. 1983, 40, 903-911. [CrossRef] [PubMed]

126. Clarke, A.J.; Dupont, C. O-Acetylated peptidoglycan: Its occurrence, pathobiological significance, and biosynthesis. Can. J. Microbiol. 1992, 38, 85-91. [CrossRef] [PubMed]

127. Weadge, J.T.; Pfeffer, J.M.; Clarke, A.J. Identification of a new family of enzymes with potential $O$-acetylpeptidoglycan esterase activity in both Gram-positive and Gram-negative bacteria. BMC Microbiol. 2005, 5, 49. [CrossRef] [PubMed]

128. Moynihan, P.J.; Clarke, A.J. O-acetylation of peptidoglycan in gram-negative bacteria. Identification and characterization of peptidoglycan O-acetyltransferase in Neisseria gonorrhoeae. J. Biol. Chem. 2010, 285, 13264-13273. [CrossRef]

129. Brott, A.S.; Jones, C.S.; Clarke, A.J. Development of a high throughput screen for the identification of inhibitors of peptidoglycan O-acetyltransferases, new potential antibacterial targets. Antibiotics 2019, 8, 65. [CrossRef]

130. Brott, A.S.; Clarke, A.J. Peptidoglycan $O$-acetylation as a virulence factor: Its effect on lysozyme in the innate immune system. Antibiotics 2019, 8, 94. [CrossRef]

131. Jones, C.S.; Sychantha, D.; Howell, P.L.; Clarke, A.J. Structural basis for the O-acetyltransferase function of the extracytoplasmic domain of OatA from Staphylococcus aureus. J. Biol. Chem. 2020, 295, 8204-8213. [CrossRef]

132. Cloud, K.A.; Dillard, J.P. A lytic transglycosylase of Neisseria gonorrhoeae is involved in peptidoglycan-derived cytotoxin production. Infect. Immun. 2002, 70, 2752-2757. [CrossRef]

133. Chan, Y.A.; Hackett, K.T.; Dillard, J.P. The lytic transglycosylases of Neisseria gonorrhoeae. Microb. Drug Resist. 2012, 18, 271-279. [CrossRef]

134. Schaub, R.E.; Chan, Y.A.; Lee, M.; Hesek, D.; Mobashery, S.; Dillard, J.P. Lytic transglycosylases LtgA and LtgD perform distinct roles in remodeling, recycling and releasing peptidoglycan in Neisseria gonorrhoeae. Mol. Microbiol. 2016, 102, 865-881. [CrossRef]

135. Ragland, S.A.; Schaub, R.E.; Hackett, K.T.; Dillard, J.P.; Criss, A.K. Two lytic transglycosylases in Neisseria gonorrhoeae impart resistance to killing by lysozyme and human neutrophils. Cell. Microbiol. 2017, 19, e12662. [CrossRef] [PubMed]

136. Williams, A.H.; Wheeler, R.; Thiriau, C.; Haouz, A.; Taha, M.-K.; Boneca, I.G. Bulgecin A: The key to a broad-spectrum inhibitor that targets lytic transglycosylases. Antibiotics 2017, 6, 8. [CrossRef] [PubMed]

137. Williams, A.H.; Wheeler, R.; Deghmane, A.-E.; Santecchia, I.; Schaub, R.E.; Hicham, S.; Moya Nilges, M.; Malosse, C.; ChamotRooke, J.; Haouz, A.; et al. Defective lytic transglycosylase disrupts cell morphogenesis by hindering cell wall de-O-acetylation in Neisseria meningitidis. eLife 2020, 9, e51247. [CrossRef] [PubMed]

138. Boulanger, M.J.; Murphy, M.E.P. Crystal structure of the soluble domain of the major anaerobically induced outer membrane protein (AniA) from pathogenic Neisseria: A new class of copper-containing nitrite reductases. J. Mol. Biol. 2002, 315, 1111-1127. [CrossRef] [PubMed]

139. Falsetta, M.L.; Bair, T.B.; Ku, S.C.; vanden Hoven, R.N.; Steichen, C.T.; McEwan, A.G.; Jennings, M.P.; Apicella, M.A. Transcriptional profiling identifies the metabolic phenotype of gonococcal biofilms. Infect. Immun. 2009, 77, 3522-3532. [CrossRef]

140. Shewell, L.K.; Ku, S.C.; Schulz, B.L.; Jen, F.E.-C.; Mubaiwa, T.D.; Ketterer, M.R.; Apicella, M.A.; Jennings, M.P. Recombinant truncated AniA of pathogenic Neisseria elicits a non-native immune response and functional blocking antibodies. Biochem. Biophys. Res. Commun. 2013, 431, 215-220. [CrossRef]

141. Sikora, A.E.; Mills, R.H.; Weber, J.V.; Hamza, A.; Passow, B.W.; Romaine, A.; Williamson, Z.A.; Reed, R.W.; Zielke, R.A.; Korotkov, K.V. Peptide inhibitors targeting the Neisseria gonorrhoeae pivotal anaerobic respiration factor AniA. Antimicrob. Agents Chemother. 2017, 61, e00186-17. [CrossRef]

142. Sikora, A.; Rotkov, K.V. Peptide Inhibitors Targeting the Neisseria gonorrhoeae Pivotal Anaerobic Respiration Factor AniA. 2019. Available online: https:/ / patentscope.wipo.int/search/en/detail.jsf?docId=US279743297 (accessed on 5 September 2020).

143. Lomovskaya, O.; Warren, M.S.; Lee, A.; Galazzo, J.; Fronko, R.; Lee, M.; Blais, J.; Cho, D.; Chamberland, S.; Renau, T.; et al. Identification and characterization of inhibitors of multidrug resistance efflux pumps in Pseudomonas aeruginosa: Novel agents for combination therapy. Antimicrob. Agents Chemother. 2001, 45, 105-116. [CrossRef]

144. Akama, H.; Matsuura, T.; Kashiwagi, S.; Yoneyama, H.; Narita, S.; Tsukihara, T.; Nakagawa, A.; Nakae, T. Crystal structure of the membrane fusion protein, MexA, of the multidrug transporter in Pseudomonas aeruginosa. J. Biol. Chem. 2004, $279,25939-25942$. [CrossRef]

145. Lomovskaya, O.; Bostian, K.A. Practical applications and feasibility of efflux pump inhibitors in the clinic-A vision for applied use. Biochem. Pharmacol. 2006, 71, 910-918. [CrossRef] 
146. Lei, H.-T.; Chou, T.-H.; Su, C.-C.; Bolla, J.R.; Kumar, N.; Radhakrishnan, A.; Long, F.; Delmar, J.A.; Do, S.V.; Rajashankar, K.R.; et al. Crystal structure of the open state of the Neisseria gonorrhoeae MtrE outer membrane channel. PLoS ONE 2014, 9, e97475. [CrossRef] [PubMed]

147. Chen, S.; Connolly, K.L.; Rouquette-Loughlin, C.; D'Andrea, A.; Jerse, A.E.; Shafer, W.M. Could dampening expression of the Neisseria gonorrhoeae mtrCDE-encoded efflux pump be a strategy to preserve currently or resurrect formerly used antibiotics to treat gonorrhea? mBio 2019, 10, e01576-19. [CrossRef] [PubMed]

148. Lyu, M.; Moseng, M.A.; Reimche, J.L.; Holley, C.L.; Dhulipala, V.; Su, C.-C.; Shafer, W.M.; Yu, E.W. Cryo-EM structures of a gonococcal multidrug efflux pump illuminate a mechanism of drug recognition and resistance. mBio 2020, 11, e00996-20. [CrossRef] [PubMed]

149. Riboldi-Tunnicliffe, A.; König, B.; Jessen, S.; Weiss, M.S.; Rahfeld, J.; Hacker, J.; Fischer, G.; Hilgenfeld, R. Crystal structure of Mip, a prolylisomerase from Legionella pneumophila. Nat. Struct. Biol. 2001, 8, 779-783. [CrossRef] [PubMed]

150. Leuzzi, R.; Serino, L.; Scarselli, M.; Savino, S.; Fontana, M.R.; Monaci, E.; Taddei, A.; Fischer, G.; Rappuoli, R.; Pizza, M. Ng-MIP, a surface-exposed lipoprotein of Neisseria gonorrhoeae, has a peptidyl-prolyl cis/trans isomerase (PPIase) activity and is involved in persistence in macrophages. Mol. Microbiol. 2005, 58, 669-681. [CrossRef]

151. Reimer, A.; Seufert, F.; Weiwad, M.; Ebert, J.; Bzdyl, N.M.; Kahler, C.M.; Sarkar-Tyson, M.; Holzgrabe, U.; Rudel, T.; KozjakPavlovic, V. Inhibitors of macrophage infectivity potentiator-like PPIases affect neisserial and chlamydial pathogenicity. Int. J. Antimicrob. Agents 2016, 48, 401-408. [CrossRef]

152. Bardwell, J.C.; Lee, J.-O.; Jander, G.; Martin, N.; Belin, D.; Beckwith, J. A pathway for disulfide bond formation in vivo. Proc. Natl. Acad. Sci. USA 1993, 90, 1038-1042. [CrossRef]

153. Missiakas, D.; Georgopoulos, C.; Raina, S. Identification and characterization of the Escherichia coli gene $d s b B$, whose product is involved in the formation of disulfide bonds in vivo. Proc. Natl. Acad. Sci. USA 1993, 90, 7084-7088. [CrossRef]

154. Tinsley, C.R.; Voulhoux, R.; Beretti, J.-L.; Tommassen, J.; Nassif, X. Three homologues, including two membrane-bound proteins, of the disulfide oxidoreductase DsbA in Neisseria meningitidis: Effects on bacterial growth and biogenesis of functional type IV pili. J. Biol. Chem. 2004, 279, 27078-27087. [CrossRef]

155. Miki, T.; Okada, N.; Danbara, H. Two periplasmic disulfide oxidoreductases, DsbA and SrgA, target outer membrane protein SpiA, a component of the Salmonella pathogenicity island 2 type III secretion system. J. Biol. Chem. 2004, 279, 34631-34642. [CrossRef]

156. Sinha, S.; Ambur, O.H.; Langford, P.R.; Tønjum, T.; Kroll, J.S. Reduced DNA binding and uptake in the absence of DsbA1 and DsbA2 of Neisseria meningitidis due to inefficient folding of the outer-membrane secretin PilQ. Microbiology 2008, 154, 217-225. [CrossRef] [PubMed]

157. Malojčić, G.; Owen, R.L.; Grimshaw, J.P.A.; Glockshuber, R. Preparation and structure of the charge-transfer intermediate of the transmembrane redox catalyst DsbB. FEBS Lett. 2008, 582, 3301-3307. [CrossRef] [PubMed]

158. Totsika, M.; Heras, B.; Wurpel, D.J.; Schembri, M.A. Characterization of two homologous disulfide bond systems involved in virulence factor biogenesis in uropathogenic Escherichia coli CFT073. J. Bacteriol. 2009, 191, 3901-3908. [CrossRef] [PubMed]

159. Lafaye, C.; Iwema, T.; Carpentier, P.; Jullian-Binard, C.; Kroll, J.S.; Collet, J.-F.; Serre, L. Biochemical and structural study of the homologues of the thiol-disulfide oxidoreductase DsbA in Neisseria meningitidis. J. Mol. Biol. 2009, 392, 952-966. [CrossRef]

160. Vivian, J.P.; Scoullar, J.; Rimmer, K.; Bushell, S.R.; Beddoe, T.; Wilce, M.C.J.; Byres, E.; Boyle, T.P.; Doak, B.; Simpson, J.S.; et al. Structure and function of the oxidoreductase DsbA1 from Neisseria meningitidis. J. Mol. Biol. 2009, 394, 931-943. [CrossRef]

161. Früh, V.; Zhou, Y.; Chen, D.; Loch, C.; Eiso, A.; Grinkova, Y.N.; Verheij, H.; Sligar, S.G.; Bushweller, J.H.; Siegal, G. Application of fragment based drug discovery to membrane proteins: Biophysical identification of ligands of the integral membrane enzyme DsbB. Chem. Biol. 2010, 17, 881-891. [CrossRef]

162. Ireland, P.M.; McMahon, R.M.; Marshall, L.E.; Halili, M.; Furlong, E.; Tay, S.; Martin, J.L.; Sarkar-Tyson, M. Disarming Burkholderia pseudomallei: Structural and functional characterization of a disulfide oxidoreductase (DsbA) required for virulence in vivo. Antioxid. Redox Signal. 2014, 20, 606-617. [CrossRef]

163. Adams, L.A.; Sharma, P.; Mohanty, B.; Ilyichova, O.V.; Mulcair, M.D.; Williams, M.L.; Gleeson, E.C.; Totsika, M.; Doak, B.C.; Caria, S.; et al. Application of fragment-based screening to the design of inhibitors of Escherichia coli DsbA. Angew. Chem. Int. Ed. 2015, 54, 2179-2184. [CrossRef]

164. Landeta, C.; Blazyk, J.L.; Hatahet, F.; Meehan, B.M.; Eser, M.; Myrick, A.; Bronstain, L.; Minami, S.; Arnold, H.; Ke, N.; et al. Compounds targeting disulfide bond forming enzyme DsbB of Gram-negative bacteria. Nat. Chem. Biol. 2015, 11, 292-298. [CrossRef]

165. Halili, M.A.; Bachu, P.; Lindahl, F.; Bechara, C.; Mohanty, B.; Reid, R.C.; Scanlon, M.J.; Robinson, C.V.; Fairlie, D.P.; Martin, J.L. Small molecule inhibitors of disulfide bond formation by the bacterial DsbA-DsbB dual enzyme system. ACS Chem. Biol. 2015, 10, 957-964. [CrossRef]

166. Smith, R.P.; Paxman, J.J.; Scanlon, M.J.; Heras, B. Targeting bacterial Dsb proteins for the development of anti-virulence agents. Molecules 2016, 21, 811. [CrossRef] [PubMed]

167. McMahon, R.M.; Ireland, P.M.; Sarovich, D.S.; Petit, G.; Jenkins, C.H.; Sarkar-Tyson, M.; Currie, B.J.; Martin, J.L. Virulence of the melioidosis pathogen Burkholderia pseudomallei requires the oxidoreductase membrane protein DsbB. Infect. Immun. 2018, 86, e00938-17. [CrossRef] [PubMed] 
168. Totsika, M.; Vagenas, D.; Paxman, J.J.; Wang, G.; Dhouib, R.; Sharma, P.; Martin, J.L.; Scanlon, M.J.; Heras, B. Inhibition of diverse DsbA enzymes in multi-DsbA encoding pathogens. Antioxid. Redox Signal. 2018, 29, 653-666. [CrossRef] [PubMed]

169. Duncan, L.F.; Wang, G.; Ilyichova, O.V.; Scanlon, M.J.; Heras, B.; Abbott, B.M. The fragment-based development of a benzofuran hit as a new class of Escherichia coli DsbA inhibitors. Molecules 2019, 24, 3756. [CrossRef] [PubMed]

170. Kellogg, D.S.; Cohen, I.R.; Norins, L.C.; Schroeter, A.L.; Reising, G. Neisseria gonorrhoeae II. Colonial variation and pathogenicity during 35 months in vitro. J. Bacteriol. 1968, 96, 596-605. [CrossRef]

171. Rudel, T.; van Putten, J.P.M.; Gibbs, C.P.; Haas, R.; Meyer, T.F. Interaction of two variable proteins (PilE and PilC) required for pilus-mediated adherence of Neisseria gonorrhoeae to human epithelial cells. Mol. Microbiol. 1992, 6, 3439-3450. [CrossRef] [PubMed]

172. Seifert, H.S.; Wright, C.J.; Jerse, A.E.; Cohen, M.S.; Cannon, J.G. Multiple gonococcal pilin antigenic variants are produced during experimental human infections. J. Clin. Investig. 1994, 93, 2744-2749. [CrossRef]

173. Rudel, T.; Scheuerpflug, I.; Meyer, T.F. Neisseria PilC protein identified as type-4 pilus tip-located adhesin. Nature 1995, 373, 357-359. [CrossRef]

174. Parge, H.E.; Forest, K.T.; Hickey, M.J.; Christensen, D.A.; Getzoff, E.D.; Tainer, J.A. Structure of the fibre-forming protein pilin at 2.6 A resolution. Nature 1995, 378, 32-38. [CrossRef]

175. Wolfgang, M.; Lauer, P.; Park, H.-S.; Brossay, L.; Hébert, J.; Koomey, M. PilT mutations lead to simultaneous defects in competence for natural transformation and twitching motility in piliated Neisseria gonorrhoeae. Mol. Microbiol. 1998, 29, 321-330. [CrossRef]

176. Merz, A.J.; So, M.; Sheetz, M.P. Pilus retraction powers bacterial twitching motility. Nature 2000, 407, 98-102. [CrossRef] [PubMed]

177. Winther-Larsen, H.C.; Wolfgang, M.; Dunham, S.; Putten, J.P.M.V.; Dorward, D.; Løvold, C.; Aas, F.E.; Koomey, M. A conserved set of pilin-like molecules controls type IV pilus dynamics and organelle-associated functions in Neisseria gonorrhoeae. Mol. Microbiol. 2005, 56, 903-917. [CrossRef]

178. Craig, L.; Volkmann, N.; Arvai, A.S.; Pique, M.E.; Yeager, M.; Egelman, E.H.; Tainer, J.A. Type IV pilus structure by cryo-electron microscopy and crystallography: Implications for pilus assembly and functions. Mol. Cell 2006, 23, 651-662. [CrossRef]

179. Hobbs, M.M.; Sparling, P.F.; Cohen, M.S.; Shafer, W.M.; Deal, C.D.; Jerse, A.E. Experimental gonococcal infection in male volunteers: Cumulative experience with Neisseria gonorrhoeae strains FA1090 and MS11mkc. Front. Microbiol. 2011, 2, 123. [CrossRef] [PubMed]

180. Wang, F.; Coureuil, M.; Osinski, T.; Orlova, A.; Altindal, T.; Gesbert, G.; Nassif, X.; Egelman, E.H.; Craig, L. Cryoelectron microscopy reconstructions of the Pseudomonas aeruginosa and Neisseria gonorrhoeae type IV pili at sub-nanometer resolution. Structure 2017, 25, 1423-1435. [CrossRef] [PubMed]

181. Aubey, F.; Corre, J.-P.; Kong, Y.; Xu, X.; Obino, D.; Goussard, S.; Lapeyrere, C.; Souphron, J.; Couturier, C.; Renard, S.; et al. Inhibitors of the Neisseria meningitidis PilF ATPase provoke type IV pilus disassembly. Proc. Natl. Acad. Sci. USA 2019, 116, 8481-8486. [CrossRef] [PubMed]

182. Denis, K.; Le Bris, M.; Le Guennec, L.; Barnier, J.-P.; Faure, C.; Gouge, A.; Bouzinba-Ségard, H.; Jamet, A.; Euphrasie, D.; Durel, B.; et al. Targeting type IV pili as an antivirulence strategy against invasive meningococcal disease. Nat. Microbiol. 2019, 4, 972-984. [CrossRef] [PubMed]

183. Poole, J.; Day, C.J.; Haselhorst, T.; Jen, F.E.-C.; Torres, V.J.; Edwards, J.L.; Jennings, M.P. Repurposed drugs that block the gonococcus-complement receptor 3 interaction can prevent and cure gonococcal infection of primary human cervical epithelial cells. mBio 2020, 11, e03046-19. [CrossRef]

184. Swanson, J.; Barrera, O.; Sola, J.; Boslego, J. Expression of outer membrane protein II by gonococci in experimental gonorrhea. J. Exp. Med. 1988, 168, 2121-2129. [CrossRef]

185. Jerse, A.E.; Cohen, M.S.; Drown, P.M.; Whicker, L.G.; Isbey, S.F.; Seifert, H.S.; Cannon, J.G. Multiple gonococcal opacity proteins are expressed during experimental urethral infection in the male. J. Exp. Med. 1994, 179, 911-920. [CrossRef]

186. Schneider, H.; Cross, A.S.; Kuschner, R.A.; Taylor, D.N.; Sadoff, J.C.; Boslego, J.W.; Deal, C.D. Experimental human gonococcal urethritis: 250 Neisseria gonorrhoeae MS11mkC are infective. J. Infect. Dis. 1995, 172, 180-185. [CrossRef] [PubMed]

187. Grant, C.C.; Bos, M.P.; Belland, R.J. Proteoglycan receptor binding by Neisseria gonorrhoeae MS11 is determined by the HV-1 region of OpaA. Mol. Microbiol. 1999, 32, 233-242. [CrossRef] [PubMed]

188. Schmidt, K.A.; Deal, C.D.; Kwan, M.; Thattassery, E.; Schneider, H. Neisseria gonorrhoeae MS11mkC opacity protein expression in vitro and during human volunteer infectivity studies. Sex. Transm. Dis. 2000, 27, 278-283. [CrossRef] [PubMed]

189. Fox, D.A.; Larsson, P.; Lo, R.H.; Kroncke, B.M.; Kasson, P.M.; Columbus, L. Structure of the neisserial outer membrane protein Opa60: Loop flexibility essential to receptor recognition and bacterial engulfment. J. Am. Chem. Soc. 2014, 136, 9938-9946. [CrossRef] [PubMed]

190. Semchenko, E.A.; Everest-Dass, A.V.; Jen, F.E.-C.; Mubaiwa, T.D.; Day, C.J.; Seib, K.L. Glycointeractome of Neisseria gonorrhoeae: Identification of host glycans targeted by the gonococcus to facilitate adherence to cervical and urethral epithelial cells. $m B i o$ 2019, 10, e01339-19. [CrossRef] [PubMed]

191. Altschul, S.F.; Gish, W.; Miller, W.; Myers, E.W.; Lipman, D.J. Basic local alignment search tool. J. Mol. Biol. 1990, 215 , 403-410. [CrossRef]

192. Altschul, S.F.; Madden, T.L.; Schäffer, A.A.; Zhang, J.; Zhang, Z.; Miller, W.; Lipman, D.J. Gapped BLAST and PSI-BLAST: A new generation of protein database search programs. Nucleic Acids Res. 1997, 25, 3389-3402. [CrossRef] 
193. Berman, H.M.; Westbrook, J.; Feng, Z.; Gilliland, G.; Bhat, T.N.; Weissig, H.; Shindyalov, I.N.; Bourne, P.E. The protein data bank. Nucleic Acids Res. 2000, 28, 235-242. [CrossRef]

194. Osborn, M.J. Structure and biosynthesis of the bacterial cell wall. Annu. Rev. Biochem. 1969, 38, 501-538. [CrossRef]

195. Schleifer, K.H.; Kandler, O. Peptidoglycan types of bacterial cell walls and their taxonomic implications. Bacteriol. Rev. 1972, 36, 407-477. [CrossRef]

196. Vollmer, W.; Blanot, D.; Pedro, M.A.D. Peptidoglycan structure and architecture. FEMS Microbiol. Rev. 2008, 32, 149-167. [CrossRef] [PubMed]

197. Preston, A.; Mandrell, R.E.; Gibson, B.W.; Apicella, M.A. The lipooligosaccharides of pathogenic Gram-negative bacteria. Crit. Rev. Microbiol. 1996, 22, 139-180. [CrossRef] [PubMed]

198. Takayama, K.; Qureshi, N.; Hyver, K.; Honovich, J.; Cotter, R.J.; Mascagni, P.; Schneider, H. Characterization of a structural series of lipid A obtained from the lipopolysaccharides of Neisseria gonorrhoeae. Combined laser desorption and fast atom bombardment mass spectral analysis of high performance liquid chromatography-purified dimethyl derivatives. J. Biol. Chem. 1986, 261, 10624-10631. [PubMed]

199. Kulshin, V.A.; Zähringer, U.; Lindner, B.; Frasch, C.E.; Tsai, C.M.; Dmitriev, B.A.; Rietschel, E.T. Structural characterization of the lipid A component of pathogenic Neisseria meningitidis. J. Bacteriol. 1992, 174, 1793-1800. [CrossRef]

200. Dillard, J.P. Peptidoglycan metabolism and fragment production. In Pathogenic Neisseria: Genomics, Molecular Biology and Disease Intervention; Davies, J.K., Kahler, C.M., Eds.; Caister Academic Press: Norfolk, UK, 2014; pp. 97-114, ISBN 978-1-908230-61-4.

201. Wanty, C.; Anandan, A.; Piek, S.; Walshe, J.; Ganguly, J.; Carlson, R.W.; Stubbs, K.A.; Kahler, C.M.; Vrielink, A. The structure of the neisserial lipooligosaccharide phosphoethanolamine transferase A (LptA) required for resistance to polymyxin. J. Mol. Biol. 2013, 425, 3389-3402. [CrossRef] [PubMed]

202. John, C.M.; Liu, M.; Phillips, N.J.; Yang, Z.; Funk, C.R.; Zimmerman, L.I.; Griffiss, J.M.; Stein, D.C.; Jarvis, G.A. Lack of lipid A pyrophosphorylation and functional lptA reduces inflammation by Neisseria commensals. Infect. Immun. 2012, 80, 4014-4026. [CrossRef] [PubMed]

203. Tzeng, Y.-L.; Ambrose, K.D.; Zughaier, S.; Zhou, X.; Miller, Y.K.; Shafer, W.M.; Stephens, D.S. Cationic antimicrobial peptide resistance in Neisseria meningitidis. J. Bacteriol. 2005, 187, 5387-5396. [CrossRef]

204. Kandler, J.L.; Joseph, S.J.; Balthazar, J.T.; Dhulipala, V.; Read, T.D.; Jerse, A.E.; Shafer, W.M. Phase-variable expression of lptA modulates the resistance of Neisseria gonorrhoeae to cationic antimicrobial peptides. Antimicrob. Agents Chemother. 2014, 58, 4230-4233. [CrossRef]

205. Kahler, C.M.; Nawrocki, K.L.; Anandan, A.; Vrielink, A.; Shafer, W.M. Structure-function relationships of the neisserial EptA enzyme responsible for phosphoethanolamine decoration of lipid A: Rationale for drug targeting. Front. Microbiol. $2018,9,1922$. [CrossRef]

206. Xu, Y.; Wei, W.; Lei, S.; Lin, J.; Srinivas, S.; Feng, Y. An evolutionarily conserved mechanism for intrinsic and transferable polymyxin resistance. $m$ Bio 2018, 9, e0231-17. [CrossRef]

207. Bartley, S.; Kahler, C.M. The glycome of Neisseria spp.: How does this relate to pathogenesis? In Pathogenic Neisseria: Genomics, Molecular Biology and Disease Intervention; Davies, J.K., Kahler, C.M., Eds.; Caister Academic Press: Norfolk, UK, 2014; pp. 115-145, ISBN 978-1-908230-61-4.

208. Carbonnelle, E.; Hill, D.J.; Morand, P.; Griffiths, N.J.; Bourdoulous, S.; Murillo, I.; Nassif, X.; Virji, M. Meningococcal interactions with the host. Vaccine 2009, 27, B78-B89. [CrossRef]

209. Parsons, N.J.; Andrade, J.R.C.; Patel, P.V.; Cole, J.A.; Smith, H. Sialylation of lipopolysaccharide and loss of absorption of bactericidal antibody during conversion of gonococci to serum resistance by cytidine $5^{\prime}$-monophospho-N-acetyl neuraminic acid. Microb. Pathog. 1989, 7, 63-72. [CrossRef]

210. Mandrell, R.E.; Lesse, A.J.; Sugai, J.V.; Shero, M.; Griffiss, J.M.; Cole, J.A.; Parsons, N.J.; Smith, H.; Morse, S.A.; Apicella, M.A. In vitro and in vivo modification of Neisseria gonorrhoeae lipooligosaccharide epitope structure by sialylation. J. Exp. Med. 1990, 171, 1649-1664. [CrossRef]

211. Wetzler, L.M.; Barry, K.; Blake, M.S.; Gotschlich, E.C. Gonococcal lipooligosaccharide sialylation prevents complement-dependent killing by immune sera. Infect. Immun. 1992, 60, 39-43. [CrossRef] [PubMed]

212. Emond, J.-P.; Dublanchet, A.; Goldner, M. Kinetics of conversion of Neisseria gonorrhoeae to resistance to complement by cytidine 5'-monophospho-N-acetyl neuraminic acid. Antonie Van Leeuwenhoek 1995, 67, 281-288. [CrossRef] [PubMed]

213. Ram, S.; Sharma, A.K.; Simpson, S.D.; Gulati, S.; McQuillen, D.P.; Pangburn, M.K.; Rice, P.A. A novel sialic acid binding site on factor H mediates serum resistance of sialylated Neisseria gonorrhoeae. J. Exp. Med. 1998, 187, 743-752. [CrossRef] [PubMed]

214. Devyatyarova-Johnson, M.; Rees, I.H.; Robertson, B.D.; Turner, M.W.; Klein, N.J.; Jack, D.L. The lipopolysaccharide structures of Salmonella enterica serovar Typhimurium and Neisseria gonorrhoeae determine the attachment of human mannose-binding lectin to intact organisms. Infect. Immun. 2000, 68, 3894-3899. [CrossRef]

215. Gulati, S.; Sastry, K.; Jensenius, J.C.; Rice, P.A.; Ram, S. Regulation of the mannan-binding lectin pathway of complement on Neisseria gonorrhoeae by C1-inhibitor and $\alpha 2$-macroglobulin. J. Immunol. 2002, 168, 4078-4086. [CrossRef]

216. Blom, A.M.; Hallström, T.; Riesbeck, K. Complement evasion strategies of pathogens-Acquisition of inhibitors and beyond. Mol. Immunol. 2009, 46, 2808-2817. [CrossRef]

217. Mandrell, R.E.; Griffiss, J.M.; Smith, H.; Cole, J.A. Distribution of a lipooligosaccharide-specific sialyltransferase in pathogenic and non-pathogenic Neisseria. Microb. Pathog. 1993, 14, 315-327. [CrossRef] 
218. Matthias, K.A.; Rest, R.F. Control of pili and sialyltransferase expression in Neisseria gonorrhoeae is mediated by the transcriptional regulator CrgA. Mol. Microbiol. 2014, 91, 1120-1135. [CrossRef] [PubMed]

219. Ram, S.; Shaughnessy, J.; de Oliveira, R.B.; Lewis, L.A.; Gulati, S.; Rice, P.A. Gonococcal lipooligosaccharide sialylation: Virulence factor and target for novel immunotherapeutics. Pathog. Dis. 2017, 75, ftx049. [CrossRef] [PubMed]

220. Fleming, A. On a remarkable bacteriolytic element found in tissues and secretions. Proc. R. Soc. Lond. Ser. B Contain. Pap. Biol. Character 1922, 93, 306-317. [CrossRef]

221. Lelouard, H.; Henri, S.; De Bovis, B.; Mugnier, B.; Chollat-Namy, A.; Malissen, B.; Méresse, S.; Gorvel, J. Pathogenic bacteria and dead cells are internalized by a unique subset of Peyer's patch dendritic cells that express lysozyme. Gastroenterology 2010, 138, 173-184. [CrossRef]

222. Callewaert, L.; Michiels, C.W. Lysozymes in the animal kingdom. J. Biosci. 2010, 35, 127-160. [CrossRef]

223. Wiesner, J.; Vilcinskas, A. Antimicrobial peptides: The ancient arm of the human immune system. Virulence 2010, 1, 440-464. [CrossRef]

224. Epstein, L.A.; Chain, E. Some observations on the preparation and properties of the substrate of lysozyme. Br. J. Exp. Pathol. 1940, 21, 339-355.

225. Salton, M.R.J. The properties of lysozyme and its action on microorganisms. Bacteriol. Rev. 1957, 21, 82-100. [CrossRef]

226. McClure, R.; Nudel, K.; Massari, P.; Tjaden, B.; Su, X.; Rice, P.A.; Genco, C.A. The gonococcal transcriptome during infection of the lower genital tract in women. PLoS ONE 2015, 10, e0133982. [CrossRef]

227. Humbert, M.V.; Awanye, A.M.; Lian, L.-Y.; Derrick, J.P.; Christodoulides, M. Structure of the Neisseria Adhesin Complex Protein (ACP) and its role as a novel lysozyme inhibitor. PLoS Pathog. 2017, 13, e1006448. [CrossRef]

228. Dillard, J.P.; Hackett, K.T. Mutations affecting peptidoglycan acetylation in Neisseria gonorrhoeae and Neisseria meningitidis. Infect. Immun. 2005, 73, 5697-5705. [CrossRef] [PubMed]

229. Petersen, B.H.; Rosenthal, R.S. Complement consumption gonococcal peptidoglycan. Infect. Immun. 1982, 35, 442-448. [CrossRef] [PubMed]

230. Fleming, T.J.; Wallsmith, D.E.; Rosenthal, R.S. Arthropathic properties of gonococcal peptidoglycan fragments: Implications for the pathogenesis of disseminated gonococcal disease. Infect. Immun. 1986, 52, 600-608. [CrossRef]

231. Imada, A.; Kintaka, K.; Nakao, M.; Shinagawa, S. Bulgecin, a bacterial metabolite which in concert with $\beta$-lactam antibiotics causes bulge formation. J. Antibiot. 1982, 35, 1400-1403. [CrossRef] [PubMed]

232. Shinagawa, S.; Maki, M.; Kintaka, K.; Imada, A.; Asai, M. Isolation and characterization of bulgecins, new bacterial metabolites with bulge-inducing activity. J. Antibiot. 1985, 38, 17-23. [CrossRef] [PubMed]

233. Thunnissen, A.-M.W.H.; Rozeboom, H.J.; Kalk, K.H.; Dijkstra, B.W. Structure of the 70-kDa soluble lytic transglycosylase complexed with bulgecin A. Implications for the enzymic mechanism. Biochemistry 1995, 34, 12729-12737. [CrossRef] [PubMed]

234. Bonis, M.; Williams, A.; Guadagnini, S.; Werts, C.; Boneca, I.G. The effect of bulgecin A on peptidoglycan metabolism and physiology of Helicobacter pylori. Microb. Drug Resist. 2012, 18, 230-239. [CrossRef] [PubMed]

235. Skalweit, M.J.; Li, M. Bulgecin A as a $\beta$-lactam enhancer for carbapenem-resistant Pseudomonas aeruginosa and carbapenemresistant Acinetobacter baumannii clinical isolates containing various resistance mechanisms. Drug Des. Devel. Ther. 2016, 10, 3013-3020. [CrossRef]

236. Dik, D.A.; Madukoma, C.S.; Tomoshige, S.; Kim, C.; Lastochkin, E.; Boggess, W.C.; Fisher, J.F.; Shrout, J.D.; Mobashery, S. Slt, $\mathrm{MltD}$, and MltG of Pseudomonas aeruginosa as targets of Bulgecin A in potentiation of $\beta$-lactam antibiotics. ACS Chem. Biol. 2019, 14, 296-303. [CrossRef]

237. Greiner, L.L.; Edwards, J.L.; Shao, J.; Rabinak, C.; Entz, D.; Apicella, M.A. Biofilm formation by Neisseria gonorrhoeae. Infect. Immun. 2005, 73, 1964-1970. [CrossRef]

238. Steichen, C.T.; Shao, J.Q.; Ketterer, M.R.; Apicella, M.A. Gonococcal cervicitis: A role for biofilm in pathogenesis. J. Infect. Dis. 2008, 198, 1856-1861. [CrossRef] [PubMed]

239. Knapp, J.S.; Clark, V.L. Anaerobic growth of Neisseria gonorrhoeae coupled to nitrite reduction. Infect. Immun. 1984, 46, 176-181. [CrossRef] [PubMed]

240. Householder, T.C.; Fozo, E.M.; Cardinale, J.A.; Clark, V.L. Gonococcal nitric oxide reductase is encoded by a single gene, norB, which is required for anaerobic growth and is induced by nitric oxide. Infect. Immun. 2000, 68, 5241-5246. [CrossRef] [PubMed]

241. Clark, V.L.; Campbell, L.A.; Palermo, D.A.; Evans, T.M.; Klimpel, K.W. Induction and repression of outer membrane proteins by anaerobic growth of Neisseria gonorrhoeae. Infect. Immun. 1987, 55, 1359-1364. [CrossRef]

242. Clark, V.L.; Knapp, J.S.; Thompson, S.; Klimpel, K.W. Presence of antibodies to the major anaerobically induced gonococcal outer membrane protein in sera from patients with gonococcal infections. Microb. Pathog. 1988, 5, 381-390. [CrossRef]

243. Li, X.-Z.; Nikaido, H. Efflux-mediated drug resistance in bacteria. Drugs 2004, 64, 159-204. [CrossRef]

244. Hagman, K.E.; Pan, W.; Spratt, B.G.; Balthazar, J.T.; Judd, R.C.; Shafer, W.M. Resistance of Neisseria gonorrhoeae to antimicrobial hydrophobic agents is modulated by the mtrRCDE efflux system. Microbiology 1995, 141, 611-622. [CrossRef]

245. Rouquette-Loughlin, C.E.; Balthazar, J.T.; Shafer, W.M. Characterization of the MacA-MacB efflux system in Neisseria gonorrhoeae. J. Antimicrob. Chemother. 2005, 56, 856-860. [CrossRef]

246. Rouquette-Loughlin, C.; Dunham, S.A.; Kuhn, M.; Balthazar, J.T.; Shafer, W.M. The NorM efflux pump of Neisseria gonorrhoeae and Neisseria meningitidis recognizes antimicrobial cationic compounds. J. Bacteriol. 2003, 185, 1101-1106. [CrossRef] 
247. Lee, E.H.; Shafer, W.M. The far $A B$-encoded efflux pump mediates resistance of gonococci to long-chained antibacterial fatty acids. Mol. Microbiol. 1999, 33, 839-845. [CrossRef]

248. Warner, D.M.; Shafer, W.M.; Jerse, A.E. Clinically relevant mutations that cause derepression of the Neisseria gonorrhoeae MtrCMtrD-MtrE efflux pump system confer different levels of antimicrobial resistance and in vivo fitness. Mol. Microbiol. 2008, 70, 462-478. [CrossRef] [PubMed]

249. Wadsworth, C.B.; Arnold, B.J.; Sater, M.R.A.; Grad, Y.H. Azithromycin resistance through interspecific acquisition of an epistasisdependent efflux pump component and transcriptional regulator in Neisseria gonorrhoeae. mBio 2018, 9, e01419-18. [CrossRef] [PubMed]

250. Rouquette-Loughlin, C.E.; Reimche, J.L.; Balthazar, J.T.; Dhulipala, V.; Gernert, K.M.; Kersh, E.N.; Pham, C.D.; Pettus, K.; Abrams, A.J.; Trees, D.L.; et al. Mechanistic basis for decreased antimicrobial susceptibility in a clinical isolate of Neisseria gonorrhoeae possessing a mosaic-like $m$ tr efflux pump locus. mBio 2018, 9, e02281-18. [CrossRef] [PubMed]

251. Delahay, R.M.; Robertson, B.D.; Balthazar, J.T.; Shafer, W.M.; Ison, C.A. Involvement of the gonococcal MtrE protein in the resistance of Neisseria gonorrhoeae to toxic hydrophobic agents. Microbiology 1997, 143, 2127-2133. [CrossRef]

252. Hagman, K.E.; Lucas, C.E.; Balthazar, J.T.; Snyder, L.; Nilles, M.; Judd, R.C.; Shafer, W.M. The MtrD protein of Neisseria gonorrhoeae is a member of the resistance/nodulation/division protein family constituting part of an efflux system. Microbiology 1997, 143, 2117-2125. [CrossRef]

253. Pan, W.; Spratt, B.G. Regulation of the permeability of the gonococcal cell envelope by the mtr system. Mol. Microbiol. 1994, 11, 769-775. [CrossRef]

254. Hagman, K.E.; Shafer, W.M. Transcriptional control of the mtr efflux system of Neisseria gonorrhoeae. J. Bacteriol. 1995, 177, 4162-4165. [CrossRef]

255. Rouquette, C.; Harmon, J.B.; Shafer, W.M. Induction of the $m \operatorname{trCDE}$-encoded efflux pump system of Neisseria gonorrhoeae requires MtrA, an AraC-like protein. Mol. Microbiol. 1999, 33, 651-658. [CrossRef]

256. Shafer, W.M.; Qu, X.-D.; Waring, A.J.; Lehrer, R.I. Modulation of Neisseria gonorrhoeae susceptibility to vertebrate antibacterial peptides due to a member of the resistance/nodulation/division efflux pump family. Proc. Natl. Acad. Sci. USA 1998, 95, 1829-1833. [CrossRef]

257. Nudel, K.; McClure, R.; Moreau, M.; Briars, E.; Abrams, A.J.; Tjaden, B.; Su, X.-H.; Trees, D.; Rice, P.A.; Massari, P.; et al. Transcriptome analysis of Neisseria gonorrhoeae during natural infection reveals differential expression of antibiotic resistance determinants between men and women. mSphere 2018, 3, e00312-18. [CrossRef]

258. Watkins, W.J.; Landaverry, Y.; Léger, R.; Litman, R.; Renau, T.E.; Williams, N.; Yen, R.; Zhang, J.Z.; Chamberland, S.; Madsen, D.; et al. The relationship between physicochemical properties, in vitro activity and pharmacokinetic profiles of analogues of diamine-containing efflux pump inhibitors. Bioorg. Med. Chem. Lett. 2003, 13, 4241-4244. [CrossRef] [PubMed]

259. Ventura, S.; Villaverde, A. Protein quality in bacterial inclusion bodies. Trends Biotechnol. 2006, 24, 179-185. [CrossRef] [PubMed]

260. Hartl, F.U.; Hayer-Hartl, M. Molecular chaperones in the cytosol: From nascent chain to folded protein. Science 2002, 295, 1852-1858. [CrossRef] [PubMed]

261. Hoffmann, F.; Rinas, U. Roles of heat-shock chaperones in the production of recombinant proteins in Escherichia coli. Adv. Biochem. Eng. Biotechnol. 2004, 89, 143-161. [CrossRef] [PubMed]

262. Schiene-Fischer, C.; Yu, C. Receptor accessory folding helper enzymes: The functional role of peptidyl prolyl cis/trans isomerases. FEBS Lett. 2001, 495, 1-6. [CrossRef]

263. Bardwell, J.C.A.; McGovern, K.; Beckwith, J. Identification of a protein required for disulfide bond formation in vivo. Cell 1991, 67, 581-589. [CrossRef]

264. Brandts, J.F.; Halvorson, H.R.; Brennan, M. Consideration of the possibility that the slow step in protein denaturation reactions is due to cis-trans isomerism of proline residues. Biochemistry 1975, 14, 4953-4963. [CrossRef]

265. Lang, K.; Schmid, F.X.; Fischer, G. Catalysis of protein folding by prolyl isomerase. Nature 1987, 329, 268-270. [CrossRef]

266. Starnino, S.; Leuzzi, R.; Ghisetti, V.; De Francesco, M.A.; Cusini, M.; Impara, G.; Galluppi, E.; Pizza, M.; Stefanelli, P. Molecular analysis of two novel Neisseria gonorrhoeae virulent components: The macrophage infectivity potentiator and the outer membrane protein A. New Microbiol. 2010, 33, 167-170.

267. Humbert, M.V.; Christodoulides, M. Immunization with recombinant truncated Neisseria meningitidis-Macrophage Infectivity Potentiator (rT-Nm-MIP) protein induces murine antibodies that are cross-reactive and bactericidal for Neisseria gonorrhoeae. Vaccine 2018, 36, 3926-3936. [CrossRef]

268. Echenique-Rivera, H.; Muzzi, A.; Del Tordello, E.; Seib, K.L.; Francois, P.; Rappuoli, R.; Pizza, M.; Serruto, D. Transcriptome analysis of Neisseria meningitidis in human whole blood and mutagenesis studies identify virulence factors involved in blood survival. PLoS Pathog. 2011, 7, e1002027. [CrossRef] [PubMed]

269. Bader, M.; Muse, W.; Ballou, D.P.; Gassner, C.; Bardwell, J.C.A. Oxidative protein folding is driven by the electron transport system. Cell 1999, 98, 217-227. [CrossRef]

270. Piek, S.; Wang, Z.; Ganguly, J.; Lakey, A.M.; Bartley, S.N.; Mowlaboccus, S.; Anandan, A.; Stubbs, K.A.; Scanlon, M.J.; Vrielink, A.; et al. The role of oxidoreductases in determining the function of the neisserial lipid A phosphoethanolamine transferase required for resistance to polymyxin. PLoS ONE 2014, 9, e106513. [CrossRef] [PubMed] 
271. Landeta, C.; Meehan, B.M.; McPartland, L.; Ingendahl, L.; Hatahet, F.; Tran, N.Q.; Boyd, D.; Beckwith, J. Inhibition of virulencepromoting disulfide bond formation enzyme DsbB is blocked by mutating residues in two distinct regions. J. Biol. Chem. 2017, 292, 6529-6541. [CrossRef]

272. Winther-Larsen, H.; Hegge, F.; Wolfgang, M.; Hayes, S.; van Putten, J.; Koomey, M. Neisseria gonorrhoeae PilV, a type IV pilusassociated protein essential to human epithelial cell adherence. Proc. Natl. Acad. Sci. USA 2001, 98, 15276-15281. [CrossRef]

273. McGee, Z.A.; Johnson, A.P.; Taylor-Robinson, D. Pathogenic mechanisms of Neisseria gonorrhoeae: Observations on damage to human fallopian tubes in organ culture by gonococci of colony type 1 or type 4 . J. Infect. Dis. 1981, 143, 413-422. [CrossRef]

274. McGee, Z.A.; Stephens, D.S.; Hoffman, L.H.; Schlech, W.F.; Horn, R.G. Mechanisms of mucosal invasion by pathogenic Neisseria. Rev. Infect. Dis. 1983, 5, S708-S714. [CrossRef]

275. Mosleh, I.M.; Boxberger, H.J.; Sessler, M.J.; Meyer, T.F. Experimental infection of native human ureteral tissue with Neisseria gonorrhoeae: Adhesion, invasion, intracellular fate, exocytosis, and passage through a stratified epithelium. Infect. Immun. 1997, 65, 3391-3398. [CrossRef]

276. Craig, L.; Pique, M.E.; Tainer, J.A. Type IV pilus structure and bacterial pathogenicity. Nat. Rev. Microbiol. 2004, 2, 363-378. [CrossRef]

277. Dietrich, M.; Bartfeld, S.; Munke, R.; Lange, C.; Ogilvie, L.A.; Friedrich, A.; Meyer, T.F. Activation of NF-кB by Neisseria gonorrhoeae is associated with microcolony formation and type IV pilus retraction. Cell. Microbiol. 2011, 13, 1168-1182. [CrossRef]

278. Cahoon, L.A.; Seifert, H.S. Transcription of a cis-acting, noncoding, small RNA is required for pilin antigenic variation in Neisseria gonorrhoeae. PLoS Pathog. 2013, 9, e1003074. [CrossRef] [PubMed]

279. Stohl, E.A.; Dale, E.M.; Criss, A.K.; Seifert, H.S. Neisseria gonorrhoeae metalloprotease NGO1686 is required for full piliation, and piliation is required for resistance to $\mathrm{H}_{2} \mathrm{O}_{2}$ - and neutrophil-mediated killing. mBio 2013, 4, e00399-13. [CrossRef] [PubMed]

280. Berry, J.-L.; Pelicic, V. Exceptionally widespread nanomachines composed of type IV pilins: The prokaryotic Swiss Army knives. FEMS Microbiol. Rev. 2015, 39, 134-154. [CrossRef] [PubMed]

281. Obergfell, K.P.; Seifert, H.S. The pilin N-terminal domain maintains Neisseria gonorrhoeae transformation competence during pilus phase variation. PLoS Genet. 2016, 12, e1006069. [CrossRef]

282. Gómez-Duarte, O.G.; Dehio, M.; Guzmán, C.A.; Chhatwal, G.S.; Dehio, C.; Meyer, T.F. Binding of vitronectin to opa-expressing Neisseria gonorrhoeae mediates invasion of HeLa cells. Infect. Immun. 1997, 65, 3857-3866. [CrossRef]

283. Drake, S.L.; Koomey, M. The product of the pilQ gene is essential for the biogenesis of type IV pili in Neisseria gonorrhoeae. Mol. Microbiol. 1995, 18, 975-986. [CrossRef]

284. Tønjum, T.; Caugant, D.A.; Dunham, S.A.; Koomey, M. Structure and function of repetitive sequence elements associated with a highly polymorphic domain of the Neisseria meningitidis PilQ protein. Mol. Microbiol. 1998, 29, 111-124. [CrossRef]

285. Lauer, P.; Albertson, N.H.; Koomey, M. Conservation of genes encoding components of a type IV pilus assembly/two-step protein export pathway in Neisseria gonorrhoeae. Mol. Microbiol. 1993, 8, 357-368. [CrossRef]

286. Wolfgang, M.; Putten, J.P.M.V.; Hayes, S.F.; Koomey, M. The comP locus of Neisseria gonorrhoeae encodes a type IV prepilin that is dispensable for pilus biogenesis but essential for natural transformation. Mol. Microbiol. 1999, 31, 1345-1357. [CrossRef]

287. Freitag, N.E.; Seifert, H.S.; Koomey, M. Characterization of the pilF-pilD pilus-assembly locus of Neisseria gonorrhoeae. Mol. Microbiol. 1995, 16, 575-586. [CrossRef]

288. Cole, J.G.; Fulcher, N.B.; Jerse, A.E. Opacity proteins increase Neisseria gonorrhoeae fitness in the female genital tract due to a factor under ovarian control. Infect. Immun. 2010, 78, 1629-1641. [CrossRef] [PubMed]

289. Koch, M.L. A study of cervical cultures taken in cases of acute gonorrhea with special reference to the phases of the menstrual cycle. Am. J. Obstet. Gynecol. 1947, 54, 861-866. [CrossRef]

290. Fleitas Martínez, O.; Cardoso, M.H.; Ribeiro, S.M.; Franco, O.L. Recent advances in anti-virulence therapeutic strategies with a focus on dismantling bacterial membrane microdomains, toxin neutralization, quorum-sensing interference and biofilm inhibition. Front. Cell. Infect. Microbiol. 2019, 9, 74. [CrossRef] [PubMed]

291. Farha, M.A.; Brown, E.D. Drug repurposing for antimicrobial discovery. Nat. Microbiol. 2019, 4, 565-577. [CrossRef] [PubMed]

292. D’Angelo, F.; Baldelli, V.; Halliday, N.; Pantalone, P.; Polticelli, F.; Fiscarelli, E.; Williams, P.; Visca, P.; Leoni, L.; Rampioni, G. Identification of FDA-approved drugs as antivirulence agents targeting the pqs quorum-sensing system of Pseudomonas aeruginosa. Antimicrob. Agents Chemother. 2018, 62, e01296-18. [CrossRef]

293. Rice, P.A.; Shafer, W.M.; Ram, S.; Jerse, A.E. Neisseria gonorrhoeae: Drug resistance, mouse models, and vaccine development. Annu. Rev. Microbiol. 2017, 71, 665-686. [CrossRef]

294. Paul, S.M.; Mytelka, D.S.; Dunwiddie, C.T.; Persinger, C.C.; Munos, B.H.; Lindborg, S.R.; Schacht, A.L. How to improve R\&D productivity: The pharmaceutical industry's grand challenge. Nat. Rev. Drug Discov. 2010, 9, 203-214. [CrossRef]

295. Tyers, M.; Wright, G.D. Drug combinations: A strategy to extend the life of antibiotics in the 21st century. Nat. Rev. Microbiol. 2019, 17, 141-155. [CrossRef]

296. Chemaitelly, H.; Majed, A.; Abu-Hijleh, F.; Blondeel, K.; Matsaseng, T.C.; Kiarie, J.; Toskin, I.; Abu-Raddad, L.J. Global epidemiology of Neisseria gonorrhoeae in infertile populations: Systematic review, meta-analysis and metaregression. Sex. Transm. Infect. 2020. [CrossRef]

297. Vallely, L.M.; Egli-Gany, D.; Wand, H.; Pomat, W.S.; Homer, C.S.E.; Guy, R.; Silver, B.; Rumbold, A.R.; Kaldor, J.M.; Vallely, A.J.; et al. Adverse pregnancy and neonatal outcomes associated with Neisseria gonorrhoeae: Systematic review and meta-analysis. Sex. Transm. Infect. 2021. [CrossRef] 
298. Balzarini, J.; Van Damme, L. Microbicide drug candidates to prevent HIV infection. Lancet 2007, 369, 787-797. [CrossRef]

299. Musekiwa, A.; Fernando, N.B.; Abariga, S.A. Effectiveness of vaginal microbicides in preventing HIV transmission. Trop. Med. Int. Health 2020, 25, 790-802. [CrossRef] [PubMed]

300. Chu, H.; Slepenkin, A.; Elofsson, M.; Keyser, P.; de la Maza, L.M.; Peterson, E.M. Candidate vaginal microbicides with activity against Chlamydia trachomatis and Neisseria gonorrhoeae. Int. J. Antimicrob. Agents 2010, 36, 145-150. [CrossRef] [PubMed]

301. Pedersen, C.; Slepenkin, A.; Andersson, S.B.E.; Fagerberg, J.H.; Bergström, C.A.S.; Peterson, E.M. Formulation of the microbicide INP0341 for in vivo protection against a vaginal challenge by Chlamydia trachomatis. PLoS ONE 2014, 9, e110918. [CrossRef] 